Examining Ethnic Faultlines in Groups: A Multimethod Study of Demographic Alignment, Leadership Profiles, Coalition Formation, Intersubgroup Conflict and Group Outcomes

\author{
Katerina Bezrukova \\ The Wharton School \\ University of Pennsylvania \\ bezrukov@wharton.upenn.edu \\ and \\ Karen Jehn \\ The Wharton School \\ University of Pennsylvania \\ jehn@wharton.upenn.edu
}

This research is supported by the Solomon Asch Center for the Study of Ethnopolitical Conflict at the University of Pennsylvania, SEI Center for Advance Studies in Management of the Wharton School, and The George Harvey Program on Redefining Diversity: Value Creation Through Diversity. We would also like to thank the M-squared working paper group of the Wharton School of the University of Pennsylvania, as well as Rose Kaiser-Kadende, Elaine Zanutto, Lakshmi Ramarajaran, and John Joseph for their helpful comments. In addition, we are very grateful to Mary Braun, Madhan Gounder, Justin Du Pere, Andre Kursancew, and Vikas Keswani for their assistance in data analysis. 


\begin{abstract}
This study used multiple methods to examine the effects of group member demographic alignment on coalition formation, intersubgroup conflict, and individual and group level outcomes in common-goal groups. The study uses a 2 by 2 experimental design, crossing demographic alignment (alignment vs. no alignment) and group leadership profile (split leaders vs. no split) as between-subjects variables. Data from 5 types of measurement were used to analyze the effects of member alignment and leadership profiles. We distinguish between potential group faultlines (aligned demographic characteristics of members) and active group faultlines (members actually divide into subgroups based on the aligned demographic characteristics) and hypothesize that while potential faultlines do not automatically turn into active group divisions, leadership traits will activate divisions among group members in groups predisposed to group splits based on ethnic demographic alignment (potential group faultlines). In fact, we propose, and find, that potential faultlines, if not activated into destructive splits, can lead to positive processes and outcomes in groups. Results indicate that groups with active faultlines are more likely to form coalitions, have high levels of intersubgroup conflict and lower levels of satisfaction and group performance.
\end{abstract}

Key words: ethnic group faultlines, intersubgroup conflict, and leadership profiles 
Examining Ethnic Faultlines in Groups: A Multimethod Study of Demographic Alignment, Leadership Profiles, Coalition Formation, Intersubgroup Conflict and Group Outcomes

Group composition and its effect on group processes and outcomes is central to the study of social psychology. However, research on group diversity has shown mixed results (Riordan, 2000; Williams \& O'Reilly, 1998). Some prior studies show positive effects of demographic diversity (e.g., Eagly \& Wood, 1991; Hoffman \& Maier, 1961; Hoffman, 1978; Jackson, 1992; Zenger \& Lawrence, 1989), but others show that diversity can have negative effects on group processes (e.g., Glick, Miller, \& Huber, 1993; Jehn, Northcraft \& Neale, 1999) and performance (e.g., Ancona \& Caldwell, 1992; O’Reilly \& Flatt, 1989; Steiner, 1972). Another major criticism of past work on group diversity research is that it often, theoretically and empirically, focuses on only one diversity characteristic at a time (e.g., gender) to examine the effect on group processes (e.g., Eagly \& Wood, 1991; Harrison, Price, \& Bell, 1998) or group outcomes (e.g. Cummings, Zhou, \& Oldham, 1993; Thornburg, 1991). This research ignores that individuals possess multiple demographic characteristics (e.g., gender, race, age, nationality) and that the combination of these characteristics, as well as their alignment across group members, is critical to understanding the effects of group composition on group processes and outcomes.

Lau and Murnighan (1998) have developed a theory of group faultlines intended to remedy the shortcomings of past diversity research. They introduce a concept, group faultlines, "which depends on the compositional dynamics of the multiple demographic attributes that can potentially subdivide a group" (p. 325). Group faultlines occur in groups when a group splits into two subgroups based on the alignment of one or more demographic attributes (e.g., race and national heritage). The theory of group faultlines allows group composition researchers to make predictions about group interactions based on multiple member demographic characteristics and their alignment within the group. While the faultline construct is an intriguing new conceptualization of group composition, this theory has yet to be empirically tested. In this study we examine group faultlines based on two demographic characteristics, race and national heritage, while controlling for other demographic characteristics, and link group faultlines to coalition formation, intersubgroup conflict, and multiple group and individual outcomes.

While group conflict has also been a main focus of social psychology (e.g. Gaertner, Dovidio, Banker, Houlette, Johnson, \& McGlynn, 2000; Kessler \& Mummendey, 2001; Levine 
\& Moreland, 1990), focusing on conflict within a group or conflict between groups, we believe that the dynamics by which a group splits into subgroups, and the conflict that occurs between the subgroups that emerge within the common-goal group have been ignored. We predict that intersubgroup conflict arises from activated faultlines through coalition formation. We develop a model that includes the moderating role of leadership characteristics in aggravating or alleviating the negative effects of destructive ethnic faultline activation on group processes and outcomes.

To examine member alignment and resulting group processes, we used a multimethod approach. Much past research on group processes has used a single measurement methodology (for exceptions, see Weingart, 1992; Jehn \& Shah, 1997); however, we believe a multimethod approach is critical for understanding the social psychological processes that occur within groups. According to Cook, Campbell, \& Peracchio (1990), and others more recently (Singleton, Straits, \& Miller, 1993), construct investigation is more accurate and reliable when multiple measurement methodologies are utilized. We therefore used five measurement methodologies: pre- and post-experimental questionnaires, contextual ratings by independent raters, contentanalyzed audiotapes, observational reports with behavioral indicators, and objective measures of group performance.

\section{Group Faultline Theory}

Past research on group diversity utilizes the heterogeneity concept rather than the alignment construct we present in this paper. Group faultline theory argues that it is not only the dispersion of demographic characteristics (i.e., heterogeneity) that influence group processes and outcomes, but the alignment across members based on multiple characteristics simultaneously considered. Differences among group members exist on a number of demographic characteristics (e.g., age, race, gender); however, diversity measures have historically been unable to capture the cumulative effects of multiple differences on more than one characteristic (Thatcher, Jehn, \& Zanutto, in press). Therefore the heterogeneity concept only captures the degree to which a group differs on one demographic characteristic (e.g., race) but not how differences in sex, race, and age, for example, combine to affect group processes and outcomes. Based on faultline theory (Lau \& Murnighan, 1998), the alignment construct we introduce considers multiple characteristics of group members, the alignment of those attributes among members, and the number of potentially homogenous subgroups. An example of a group with strong alignment would be a four-person group consisting of two white females of Irish descent 
and two black men of African descent. In this group, the demographic alignment across members is clear because there are two homogenous subgroups based on their gender, race, and national heritage, and there is, according to Lau and Murnighan (1998), a strong faultline within the group. An example of a group with no alignment, or a weak faultline, would be a group of four people consisting of one Asian female from Singapore, one white female from England, one black male from Jamaica, and one Native American Indian male from the United States. In this latter group, subgroups may form around the categories of gender but the subgroups would not be as strong as in the first example because members within the subgroups that form are similar on only one dimension, gender, and differ on race and nationality.

The advantage of the alignment construct over heterogeneity is that it combines multiple demographics of individuals, taking into account the fact that individuals have multiple identities simultaneously (i.e., black, Nigerian) rather than one at a time (i.e., black) which ignores other demographic characteristics of the member (i.e., Nigerian). Thus, the alignment, or faultline, approach reconceptualizes a traditional understanding of diversity as a dispersion of a population on a single demographic characteristic (Blau, 1977) into a more sophisticated consideration of all the potential dynamics that many different characteristics when aligned can activate (Lau \& Murnighan, 1998).

\section{A Model of Ethnic Group Faultlines, Group Processes, and Outcomes}

\section{Potential versus Active Ethnic Group Faultines}

Similar to the geological concept of faults in the Earth's crust, ethnic faultlines in groups can be inactive and go unnoticed for years without any changes in group processes (Lau \& Murnighan, 1998). We therefore distinguish between potential group faultlines and active group faultlines. Potential faultlines refer to hypothetical dividing lines that split a group into subgroups based on demographic alignment across members. Active group faultlines occur in groups when members perceive these divisions and the group splits into two subgroups based on the alignment of two or more demographic attributes (e.g., race and national heritage). While potential faultlines are based on the objective demographics of group members, active group faultlines exist when the members perceive and behave as if they are two separate, different (and potentially even opposed) subgroups. This perception is more likely to form when potential faultlines exist and are evident in a group. While potential faultlines do not necessarily turn into active group divisions, we propose that certain leadership traits and leader profiles within the 
group (one leader vs. two leaders) will activate potential divisions among group members in groups predisposed to group splits based on faultlines. In fact, we propose, and find, that potential faultlines, if not negatively activated into destructive splits, can enhance positive group processes and outcomes.

In this study, we focus on two demographic attributes: race (e.g. Asian, White, etc.) and national heritage (e.g. Irish, Chinese, etc) to examine their alignment as a cause of coalition formation and conflict. We define race as a person's racial group membership(s) as determined by his or her biological parents' ancestry, transmitted through and fixed by birth (adapted from Hirschfeld, 1996; Singh, 1977). The salience of race in people's spontaneous self-concept has proven to be important for its impact on interpersonal attraction and intergroup conflict (McGuire, McGuire, Child, \& Fujioka, 1978). Following Connor (1994) and Verdery (1993), we define national heritage as one's psychological bond to a community of people characterized by a common language, territory, religion, history or broader cultural identity. Race is traditionally categorized into five categories in the United States (where the current study took place): White, Black or African American, Asian, Hispanic or Latino, and American Indian or Alaskan Native (Frable, 1997; Nkomo, 1992; U.S. Census Bureau, 2002), while national heritage refers to the origins of one's ancestors (i.e. Polish, English, Russian, etc.).

Individuals have multiple demographic identities (McBeth, 1989; Nagel, 1994). For instance, race as one of demographic characteristics might represent one aspect of an individual's identity whereas national heritage symbolizes another. We propose that these multiple demographic identities should be considered simultaneously to accurately represent the individual within the group. Waters (1996) reports that in the U.S., dark-skinned Caribbean immigrants acknowledge and emphasize color and racial similarities with African-Americans, however, they culturally distinguish themselves from native-born blacks. Similarly, Espiritu (1992) finds that individuals who identify themselves racially as Asian also tend to stress their culturally distinct national heritages (e.g. Japanese, Chinese, Vietnamese). Padilla (1985) also discusses how Mexican-American and Puerto Ricans in Chicago place importance on their different national heritages in their construction of their ethnic identity, combining their racial Hispanic identity and their national heritage.

Based on faultline theory, groups in which all members have the same self-proposed race and national heritage will, by definition, have no potential for ethnic faultlines. For example, if 
all group members are white and of Irish heritage, there will be no potential for faultlines to occur based on race and national heritage ${ }^{1}$. In contrast, if a group of four members consists of two African-Americans of African descent and two members who are Caucasian-Americans of Irish decent, there is a much higher potential that a faultline will occur within this group based on race and national heritage. Alignment across the two demographic categories represented by an equal number of group members is likely to create a potential for group bifurcation due to this alignment along racial and national heritage lines. When groups have members who each differ on race (e.g., one White member, one Black member, one Latino member, and one Asian member) this diffuses the likelihood of racially motivated alliances especially if they all have different national heritages as well.

According to Lau and Murnighan (1998), faultlines can lead to salient subgroups that then become a basis for categorization and social identification within subgroups. Since people tend to gravitate towards those who share similar race and national heritage characteristics (e.g. Nagel, 1994; Verdery, 1993; Weber, 1997), the alignment of individuals along these characteristics can create the potential for activated ethnic faultlines. Once group members start identifying themselves with a particular subgroup, the negative outcomes of categorization (e.g. negative stereotyping and prejudice) can activate group faultlines. Note, however, that not all potential ethnic faultline situations are necessarily activated; that is, while the demographics of the group members suggest the potential for ethnic faultlines, the members may never actually feel or behave as separate groups; that is, there may be no perceived differences across ethnic boundaries by members. We hypothesize that the characteristics of the group leaders and the leadership profiles within the groups will determine whether or not the faultlines are activated.

\section{Group Leadership Profiles}

We propose that the presence of strong and authoritarian leaders can increase the likelihood of faultline activation. We discuss two components of leadership (ethnic identity and entitlement beliefs) as factors of the group leadership profile which can create an environment in which potential ethnic faultlines are likely to become activated. We propose that the strength of a

\footnotetext{
${ }^{1}$ Note, however, that faultlines can occur based on other demographic constructs in groups, such as gender. For a full discussion of the theory of faultlines, see Lau and Murnighan (1998). In this paper we focus on ethnic faultlines, combining race and ethnic heritage. In addition, we control for other demographics on which faultlines can occur, such as gender and age. We consider this a conservative test of the effects of group faultlines given that we utilize only two characteristics in our alignment construct.
} 
leader's ethnic identity and sense of entitlement are likely to determine whether ethnic faultlines are encouraged or tolerated within groups.

We define ethnic identity as that part of a leader's self-concept that is derived from his or her perception of membership in an ethnic group, together with the value and emotional significance attached to that membership (adapted from Tajfel, 1982). Ethnic identity serves as a basis for comparison across groups, defines the status of the ethnic group within the larger society, and can be viewed as a precondition for ethnic superiority (Mullick \& Hraba, 2001; Phinney, 1996). Individuals may find identification with their leaders' racial and ethnic groups beneficial as a way of gaining access to limited resources (Hardin, 1995). Ethnic identities provide a frame of reference from which group leaders can initiate, maintain, and structure their relationships with other group members (Brewer, 2000) and create the group environment in which faultlines are likely to be activated. In particular, the leaders with a strong sense of ethnic identity may be involved in the process of constructing antagonistic relationships with group members of different race and national heritage in order to strengthen their hold on power (Fearon \& Laitin, 2000). Through the process of this ethnocentric projection, the differences between ingroup and outgroup members are likely to amplify, causing subgroup boundaries to emerge (Dovidio, Kawakami, \& Gaertner, 2002; Gaertner \& Dovidio, 2000) and lead to faultline activation.

Human history provides many examples of abusive tyrants and dictators (e.g. Hitler, Stalin) who possessed narcissistic personalities, had entitlement beliefs, and intensively exploited the idea of nationalism to emphasize conflict between races or classes (Chirot, 1997). We define entitlement beliefs as the feeling of deserving, regardless of effort, held by the leader (adapted from Moore, 1991). This construct is one aspect of the narcissistic personality dimension (Raskin \& Terry, 1988) which is often associated with arrogance, conceit, and even violence (Baumeister, Smart, \& Boden, 1996; Kirkpatrick, Waugh, Valencia, \& Webster, 2002). Narcissistic people are predisposed to compete for glory and power and hence, are likely to establish themselves as the center of a group's communication network (Duckitt, 1989; Raskin, Novacek, \& Hogan, 1991). The high level of self-perceived superiority possessed by such individuals has also been shown to be related to aggression (Kirkpatrick et al., 2002). We argue that entitlement beliefs, as a component of narcissism which is usually associated with authority seeking, exhibitionism, and grandiosity (Dowson, 1992; Raskin \& Terry, 1988; Silverman \& 
Williamson, 1997), can reflect this influential ability of leaders to trigger the activation of potential ethnic faultlines.

Hogan, Raskin, and Fazzini (1990) note, that managers with a strong sense of entitlement make judgments with greater confidence and become disproportionally more influential in group situations. They are likely to be perceived by other group members as socially attractive (Hogg, Hains, \& Mason, 1998) and may use their position of power to magnetize their followers (Hogg $\&$ Reid, 2001). When in a leadership position with the opportunity for self-enhancement, such individuals may be attracted to the potential glory (Wallace \& Baumeister, 2002) and their view of themselves as high performers can generate followership within a group. As racial and national heritage attributes of group members can serve as a basis for social hierarchy and dominance (Pratto, Sidanius, \& Stallworth, 1993), leaders with a strong sense of entitlement may formulate their strategies around these demographic attributes. Furthermore, literature on dominant coalitions and power distribution suggest that power imbalance may trigger coalitional activity resulting in subgroup formation (Mannix, 1993; Pearce \& DeNisi, 1983). Since leaders require complimentary followers, a group consisting of more than one leader may experience polarization over leadership and inevitable conflict over power (Barry \& Stewart, 1997). Equally weighted centers of potential power within a group might give a rise to emergence of competing and nonoverlapping subgroups (Lau \& Murnighan, 1998; Murnighan \& Brass, 1991). We suggest that this influential ability of two leaders, each with a strong sense of entitlement, may promote the process whereby potential ethnic faultlines actually become active divides along racial and national heritage lines within a group.

In sum, we propose that groups which have leaders with strong ethnic identification and entitlement beliefs will be more likely to activate potential ethnic faultlines into actual faultlines than groups without leaders fitting this profile. We especially think this is likely if two leaders with strong ethnic identification and entitlement beliefs exist within one group.

\section{Coalition Formation and Intersubgroup Conflict}

We further propose that the faultline construct and the processes of coalition formation and intersubgroup conflict are related. We define a coalition as two or more parties who cooperate to obtain a mutually desired outcome that satisfies the interests of the coalition rather than those of the entire group within which it is embedded (Komorita \& Kravitz, 1983). In a recent study of interpersonal and intergroup relations, LaBianca, Brass, and Gray (1998) suggest 
that coalition formation and intergroup competition drive perceptions of intergroup conflict. In examining intergroup conflict within a group that splits, we define this intersubgroup conflict as perceived incompatibilities or perceptions by the parties involved that they hold discrepant views from members of the other subgroup. We extend the traditional literature on group conflict that proposes two types of intragroup conflict, task and relationship (Amason, 1996; Jehn, 1995; Jehn, Northcraft, \& Neale, 1999; Pelled, 1996; Shah \& Jehn, 1993), by conceptualizing the two types of conflict in the context of intersubgroup relationships rather than as a general group-level construct. Consistent with past work on interindividual-intergroup discontinuity theory (Insko et al., 1993; Insko et al., 2001; Insko, Schopler, Hoyle, Dardis, \& Graetz, 1990; Insko et al., 1998; Schopler, Insko, Graetz, Drigotas, Smith, \& Dahl, 1993; Wildschut, Insko, \& Gaertner, 2002), we propose that intersubgroup relations may be more competitive, less trusting, and more conflictful than those between two individuals or in a group that does not have faultline splits.

It has been argued that people form coalitions on the basis of agreement on issues or similar definitions of their task situation (Murnighan \& Brass, 1991). Stevenson, Pearce, and Porter (1985) describe how group members band together in pursuing subgroup goals with the consequent possibility of coalition formation. Coalitions can also form when group members identify themselves with a smaller subgroup within the larger group based on their demographic similarity. For example, Eisenhardt and Bourgeois (1988) found that demographic similarity of group members predicted coalition patterns through the processes of initial attraction and social integration of group members. Members of these coalitions often maintain separate subgroup identities along coalitional lines in order to preserve their unique subgroup traditions and cultures (Deutsch, 1973) and to provide support for the shared self-interest within a subgroup which can lead to competition with another group (Insko \& Schopler, 1987; Wildschut, Insko, \& Gaertner, 2002). The recognition of the existence of two distinct coalitions is likely to amplify the salience of in-group/out-group membership, which often leads to intergroup biases (Polzer, Mannix, \& Neale, 1998; Sherif, Harvey, White, Hood, \& Sherif, 1961). The underlying mechanism of this tendency to favor one's own group over another is based on mutual intergroup comparison (Tajfel \& Turner, 1986). Tajfel and Turner (1986) claim that this kind of association is necessary, and often sufficient, for social competition over scarce resources or power. Empirical research has shown that competition could cause strain and polarization between subgroups and lead to opposition (Hogg, Turner, \& Davidson, 1990; Insko et al., 1993; Rabbie \& Bekkers, 
1978; Tyerman \& Spencer, 1983). Since opposition is usually perceived as a threat from the outgroup, it tends to increase ingroup solidarity and give rise to outgroup stereotypes and negative images (Insko \& Schopler, 1998; Levine \& Moreland, 1990). These group processes are likely to lead to intensification of conflict between subgroups and therefore, in extreme cases, promote or activate inter-coalitional, or intersubgroup conflict.

\section{Coalitions, Intersubgroup Conflict and Group Outcomes}

The multiparty negotiation and coalition literature suggest that once a coalition is formed, the parties in the coalition continue to cooperate with each other, favorably influencing their own outcomes at the expense of noncoalition members (Polzer, Mannix, \& Neale, 1998). This coalition formation may promote subgroup identification which breeds strong intragroup trust and loyalty and promotes intergroup distrust and social competition (Brewer, 1996; Insko \& Schopler, 1998; Insko et al., 1993). Implicit competition between coalitions may interfere with the individual's ability or willingness to make choices that benefit all members of a group (Brewer, 1995). Furthermore, Thompson, Mannix, and Bazerman (1988) showed that coalition formation had detrimental effects for group negotiation processes and outcomes due to unequal distribution of resources between members. In particular, due to the emerging power differentiation, coalition formation may restrict access to important resources and hence, deprive another subset of group members who do not belong to the dominant coalition (Mannix, 1993). Since group outcomes are generally viewed as an aggregate of performance or a group product, we propose that coalition formation within a group will likely lead to lower levels of group productivity and performance, and that the negative processes and possible inequities will also lead to decreased satisfaction with overall group outcomes (Gillespie, Brett, \& Weingart, 2000).

Because of negative categorization processes, subgroups are likely to experience frustration, discomfort, hostility, and anxiety that can result in relationship conflict between the two subgroups. Relationship conflicts are disagreements and incompatibilities between two subgroups within a group about issues that are not task related, but that focus on personal issues. Relationship conflicts frequently reported are about social events, gossip, clothing preferences, political views, and hobbies (Jehn, 1997). This type of conflict often is associated with animosity and annoyance among individuals within a group (Amason \& Schweiger, 1997; Amason, 1996; Pelled, 1996) and we specify the conflict that occurs specifically between individuals belonging to different subgroups as the result of activated ethnic faultlines. 
Intersubgroup relationship conflicts can cause extreme negative process problems such as lack of coordination, cooperation, and cohesion (Brewer, 1995, 1996; LaBianca, Brass, \& Gray, 1998). These conflicts deplete energy and effort that could be expended toward task completion and consolidation around mutual goals (Amason \& Mooney, 1999; Northcraft, Polzer, Neale, \& Kramer, 1995). It has been shown that relationship conflict has negative effects and is responsible for outcomes such as increased turnover, high rates of absenteeism, decreased satisfaction, low levels of perceived performance, poor objective performance, lack of creativity, and low commitment (Amason, 1996; Baron, 1991; Jehn, 1995; Jehn et al., 1997; Pelled, 1996; Simons \& Peterson, 2000). Therefore, we predict, specifically, that groups with high levels of intersubgroup relationship conflict will have lower levels of satisfaction, group performance, and creativity.

Intersubgroup task conflicts are disagreements between members of two subgroups within a group around ideas and opinions about the task being performed, such as disagreement regarding a group's work plan or the specifications of the final product. Task conflict, which is focused on content-related issues, can enhance performance quality (Jehn, Northcraft, \& Neale, 1999). For example, critical debate among members of two different subgroups and open discussion regarding task issues increases group performance because members are more likely to offer and evaluate various solutions, thus reaching optimal decisions and outcomes (Amason, 1996; Cosie, Richard, \& Rose, 1977; Schweiger, Sandberg, \& Rechner, 1989). However, conflict in any form can be an uncomfortable environment, decreasing individuals' perceptions of teamwork and their satisfaction (Amason \& Schweiger, 1997). We predict, therefore, that intersubgroup task conflict while enhancing group performance and creativity, will decrease individual member satisfaction.

Our hypotheses can be summarized as follows:

Hypothesis 1: Groups with potential ethnic faultlines (demographic member alignment across race and national heritage lines) and with leadership profiles of two leaders with strong ethnic identity and strong entitlement beliefs will be more likely to have activated ethnic faultlines than groups with low ethnic faultline potential.

Hypothesis 2: Groups with activated group faultlines will be more likely to engage in coalition formation, intersubgroup relationship conflict, and intersubgroup task conflict than groups with no active faultlines. 
Hypothesis 3: Groups with subgroup coalitions will be more likely to have lower levels of member satisfaction, performance, and creativity than groups without coalitions. Hypothesis 4: Groups with intersubgroup relationship conflict will be more likely to have low levels of member satisfaction, performance, and creativity than groups with low levels of intersubgroup relationship conflict.

Hypothesis 5: Groups with intersubgroup task conflict will be more likely to have low levels of member satisfaction, and higher levels of performance and creativity than groups with low levels of intersubgroup task conflict.

\section{Method}

\section{Sample}

Ninety undergraduate students (26 three-, four-, and five-person groups) from an East Coast university participated in the experiment. Two groups were dropped from the analysis because of insufficient data, leaving a sample of $\underline{N}=86$ (a total of 24 groups). The mean age of the participants was 20.3 years (range $=17-22$ years). The majority of the participants $(44.3 \%)$ were white; $23.5 \%$ were Asian; $6.1 \%$ were black; and .9\% were Hispanic. The participants primarily identified themselves with 22 national heritages: the most often mentioned were Polish (9.4\%), Korean and Indian (both are 8.7\%), Italian (7\%), Chinese (6.1\%), and Irish (5.2\%). The participants also identified secondary national heritages: the most often mentioned secondary heritages were German (14.8\%), Irish (13.9\%), English (7.8\%), and Russian (5.2\%). Forty eight percent of the participants were female.

\section{Experimental Manipulations}

We used a 2 x 2 between-subjects experimental design crossing potential ethnic faultlines (groups with strong potential faultlines vs. groups with weak potential faultlines) and group leadership profile (2 leaders with strong ethnic identification and strong entitlement beliefs vs. groups without such leaders). One month before the study, participants were asked to provide information about their race, national heritage, and other individual characteristics (e.g., entitlement beliefs and ethnic identity). Groups were formed using this information. Some groups were composed of participants representing two races and national heritages (e.g. two Asian-Chinese students and two white-Irish students) creating the strong potential faultline condition. Other groups were composed with either racially and nationally homogeneous participants (e.g. all white Irish) or racially and nationally heterogeneous participants (e.g. one 
Asian-Chinese, one white-Irish, one Hispanic-Colombian, and one black-Barbadian) creating the weak potential faultline condition. All participants' ethnic identity strength and entitlement beliefs were assessed. Groups were formed with two different leadership profiles: either two leaders with strong entitlement beliefs and strong ethnic identities or no leaders with these strong characteristics.

\section{Task Procedure}

A task we called the "Tower Building Competition Simulation" was performed by all groups. Each group was asked to build the tallest tower possible using only a pack of toothpicks, a pack of pipe cleaners, a bag of marshmallows, a pack of construction paper, a pair of scissors, a stapler, and a pack of markers. Participants were told that the base of the tower needed to be on the floor and that the tower must be freestanding. The participants were told that they were participating in a group process and team performance study and were debriefed after the completion of the study.

The Tower Building Competition Simulation had three distinct phases. In Phase I: Individual Plans, each team member worked independently to create a plan for building the tallest tower possible using only the supplied materials. Each participant drew a schematic diagram and provided a set of instructions for construction. They were given seven minutes to perform this task. In Phase II: Two Group Plans, the members of the group came together and selected two plans to be turned in. In Phase II, participants also had to choose which plan, if either, they were going to use to construct the tower. On the backside of each submitted plan, the students were instructed to write the creator of the plan's name and were asked to indicate which plan(s) were going to be used to build the tower. They were given ten minutes to complete this section. In Phase III: Build The Tallest Tower, the teams set to work and built their towers. They were given fifteen minutes to build the tallest freestanding tower possible. Groups were audio taped during all three phases of the experiment. After Phase III, the experimenters distributed a post-experimental questionnaire and raters blind to hypotheses and conditions determined which team had the tallest tower and ranked the performance and creativity of each team. After the questionnaires were completed, participants were carefully debriefed about the goal and the purpose of the exercise, winners were awarded, and all participants were thanked. 


\section{Measurement Methodologies}

To rigorously operationalize the constructs under study, we used five measurement methodologies: contextual ratings by independent raters, content-analyzed audiotapes, pre- and post-experimental questionnaires (the items were interspersed to avert consistency or order effects), observational reports with behavior indicators, and objective measures of group performance. We discuss the triangulation of these multiple methods in our construct validation section below. We adapted the Faultline algorithm developed by Thatcher, Jehn, and Zanutto (in press) to measure potential faultline strength.

Contextual ratings. Two raters who were unaware of the hypotheses and experimental conditions listened to each group's audiotape and rated the constructs under study. They were given definitions of each construct and were asked questions such as "To what extent does this team split into subgroups based on demographic characteristics?" (activated faultlines) or "To what extent have coalitions formed in this team?" (coalition formation). For each variable, the raters were asked to assign a score on a scale of 1 to $5(1=$ not at all and $5=\mathrm{a}$ lot $)$. When raters assigned the score farther than one point apart, they discussed an issue until they reached an agreement. The average inter-rater agreement was $92 \%$. The items are included in the factor analyses tables.

Content-analyzed audiotapes. Two raters blind to hypotheses and conditions conducted the content analysis of verbatim transcribed audio tapes utilizing a multi-step procedure. First, an individual who was familiar with the participants identified group members within each team and checked for accuracy of transcription by randomly selecting segments from the audiotapes and comparing them with the transcripts. The results showed that the discussions were accurately transcribed. Second, two raters divided each transcript into "thought units" based on the procedure described by Weldon, Jehn, and Pradhan (1991). A thought unit is "a sequence of a few words conveying a single thought” (Weldon, Jehn, \& Pradhan, 1991). Third, following a similar procedure to Jehn and Shah (1997), they classified all thought units into content categories directly relevant to the proposed research model: active group faultlines, coalitions, intersubgroup conflict (task and relationship), member satisfaction, creativity, and performance (see Appendix for the descriptions of content categories and coding procedure). The average inter-rater agreement was $97 \%$. 
Potential Ethnic Faultlines. Potential ethnic faultlines were measured using a faultline algorithm developed by Thatcher, Jehn, and Zanutto (in press). This Fau measure calculates the percent of total variation in overall group characteristics accounted for by the strongest group split by calculating the ratio of the between group sum of squares to the total sum of squares:

$$
\operatorname{Fau}_{g}=\left(\frac{\sum_{j=1}^{p} \sum_{k=1}^{2} n_{k}^{g}\left(\bar{x}_{\bullet j k}-\bar{x}_{\bullet j}\right)^{2}}{\sum_{j=1}^{p} \sum_{k=1}^{2} \sum_{i=1}^{n_{k}^{g}}\left(x_{i j k}-\bar{x}_{\bullet \cdot \bullet}\right)^{2}}\right) \quad g=1,2, \ldots S,
$$

where $x_{i j k}$ denotes the value of the $j^{\text {th }}$ characteristic of the $i^{\text {th }}$ member of subgroup $k, \bar{x}_{\bullet} \cdot$ denotes the overall group mean of characteristic $j, \bar{x}_{\bullet j k}$ denotes the mean of characteristic $j$ in subgroup $k$, and $n_{k}^{g}$ denotes the number of members of the $k^{\text {th }}$ subgroup $(k=1,2)$ under split $g$. The faultine strength is then calculated as the maximum value of $F_{g a u_{g}}$ over all possible splits $g=1,2, \ldots S$.

Potential ethnic faultlines were measured along two social category demographic characteristics (race and national heritage). The race variable was coded into five categories (White, Black or African American, Asian, Hispanic or Latino, and American Indian or Alaskan Native based on Frable, 1997; Nkomo, 1992; U.S. Census Bureau, 2002). The national heritage variable was coded into as many categories as were identified by the participants, which was twenty-nine. Since participants were asked to identify their single race and rank their multiple national heritages ( 1 stands for highest percent of national heritage, and 2 stands for all other national heritages (adapted from Yancey, Aneshensel, \& Driscoll, 2001), we recoded these single races and multiple national heritages as follows. We assumed that primary national heritage is twice as influential as secondary national heritage and weighted it accordingly. We considered someone to be $100 \%$ Nigerian if that was the only national heritage identified. We recorded a participant's total national heritage as $2 / 3$ Italian and 1/3 German if he or she identified Italian as primary and German as their secondary national heritage. A participant was considered 2/3 English and 1/6 German and 1/6 Irish if he or she identified one primary and two secondary national heritages. We refined the Fau algorithm to incorporate these respective weights for primary and secondary national heritages. Possible values of Fau ranged from 0.46 (weak faultline strength) to 1 (very strong faultline strength).

Process Observer Measures. Observers used Structured Observational Reports to capture behavioral indications of coalition formation and intersubgroup conflict utilizing 
conversational analysis (Goodwin \& Heritage, 1990). Conversational analysis is a disciplined way of studying the communication within interactional episodes (Ten Have, 1986). The observers measured coalitions by assessing the direction of conversation. The sample items were "Who works with whom?," "Did coalitions form? And, if so, who was in each coalition?" They measured intersubgroup relationship and task conflict by indicating how often group members disagreed about non-work (social or personality) things or task things and specifying who disagreed with whom. These observational reports taken during the study provided additional verification of our measures of coalition formation and intersubgroup conflict.

Pre - and Post - Experimental Questionnaire. We collected self-reports on perceived active faultlines, coalition formation, intersubgroup conflict, and member satisfaction before and after the simulation.

INSERT TABLE 1, 2, and 3 ABOUT HERE-------

We assessed active group faultlines with three items (e.g., "My team split into subgroups during this exercise", "My team broke into two groups during this exercise"). Participants were also asked open-ended questions such as "If your group split into two groups, on what characteristic did your team split into subgroups (e.g. race, gender, major, etc.)”.

We assessed coalitions with items such as "My team members were trying to form coalitions during this exercise" and "People built alliances in my team during this exercise". In addition, we asked open-ended questions such as "Which of your team members did you feel closest to interpersonally during this exercise?" We also adapted the two-item index of perceived utility of alliance, developed initially by Lawler and Youngs (1975), to measure coalitions (e.g. "I have more to gain by supporting Team Member A than by supporting Team Members B and C'). Team members indicated the member(s) of the coalition and reported the extent to which they agreed or disagreed with each statement by answering on a 5-point scale, labeled "strongly disagree" at one end and "strongly agree" at the other.

Intersubgroup conflict (task and relationship-based) was measured using items adapted for the intersubgroup level of analysis based on Jehn's (1995) items. For example, instead of asking how much task conflict was in the group as in Jehn's Intragroup Conflict Scale, we adapted the item to "How much task conflict was there between the two subgroups within your group?" The specific items are provided in the Factor Analysis Table 1, 2, and 3. 
We also included items for our manipulation checks on leadership profiles and characteristics. Ethnic identity items came from various sources (Der-Karabetian, 1980; Driedger, 1976; Krate, Leventhal, \& Silverstein, 1974; Morten \& Atkinson, 1983; Phinney, 1992; Rosenthal \& Hrynevich, 1985). The measure of entitlement included 20 items: 15 items came from the Narcissistic Personality Inventory developed by Raskin and Terry (1988), and 5 new items were added.

\section{Scale Development}

To develop scales for our variables we performed a principal component analysis with an oblique rotation including items from each of the five measurement methodologies (see Tables 1, 2 , and 3$)$.

Active Faultines, Coalitions, Ethnic Identity, and Entitlement. A four-component solution was found based on the scree test and eigenvalues above 1.0. The first component included five items from the post-experimental questionnaire that measured ethnic identity (Cronbach's $\alpha=.94)$. Entitlement was reflected in the second component by content-analyzed verbatim rating, contextual rating, and four items from the post-experimental questionnaire (Cronbach's $\alpha=.83$ ). The third component included the faultline score based on an open-ended item from the post-experimental questionnaire, the content-analyzed verbatim rating, the contextual rating, and three items from the post-experimental questionnaire that measured active faultlines (Cronbach's $\alpha=.84$ ). Finally, the fourth component included the contextual rating and

three items from the post-experimental questionnaire that measured coalitions within groups. The Cronbach's $\alpha$ was .75. See examples of content coding in the appendix and the postexperimental questionnaire items in Table 1.

Intersubgroup Conflict. A two-component solution was found based on the scree test and eigenvalues above 1.0. The first component included the content-analyzed verbatim rating, the contextual rating, and four items from the post-experimental questionnaire that measured intersubgroup task conflict (Cronbach's $\alpha=.83$ ). The second component included the contentanalyzed verbatim rating, the contextual rating, and two items from the post-experimental questionnaire that measured intersubgroup relationship conflict (Cronbach's $\alpha=.68$ ).

Group and Individual Member Outcomes. We used a number of different methods to measure team outcomes. First, we used the objective measure of motor task performance that was based on the height of the tower constructed by a group. This measure of performance was 
adjusted by dividing an absolute height by the height of the tallest group tower in each section; we therefore get a percentage that is consistent between all sections regardless of supplies. Second, we used the observers' measure of creativity (creative and innovative usage of supplies constituting the tower), content analyzed verbatim, contextual ratings, and self-reports. A threecomponent solution was found based on the scree test and eigenvalues above 1.00. The first component included the contextual rating and six items from the post-experimental questionnaire that measured individual satisfaction (Cronbach's $\alpha=.91$ ). The second component included the contextual rating and five items from the post-experimental questionnaire that measured perceived performance (Cronbach's $\alpha=.94$ ). Finally, creativity was the third factor and included the contextual rating and the observers' rating of creativity (Cronbach's $\alpha=.63$ ).

The principal-component and reliability analyses indicate that there is consistency across methods of measurement and that triangulation of multiple methods is appropriate and robust. For group-level analysis of our group-level dependent variables (see Rousseau, 1985), we averaged individual-level scales across groups to produce group scores of the factors. To justify aggregation, we performed the $e t a$-squared statistics, which indicates whether any two people within the same group are more similar than two people from different groups. Eta-squared statistics for active group faultlines, coalitions, intersubgroup relationship conflict, intersubgroup task conflict, perceived performance, and satisfaction were $.70, .42, .79, .73, .78, .48$, respectively. These results exceeded .20 for all factors, indicating that it was appropriate to aggregate the factors to the group level (Georgopoulos, 1986).

\section{Manipulation checks}

After scales were developed, we examined the differences across the faultline and leadership conditions. A number of items assessed the construct of ethnic faultlines and all were significantly different in the expected direction across conditions. Participants in the low potential ethnic faultlines (low alignment potential) were significantly more likely to rate their groups as racially homogeneous groups on the experimental questionnaire, $M=4.06(S D=$ 1.30), with $1=$ not at all and $5=$ a lot, than were participants in high potential faultline groups when responding to the item "Do you believe that your group is racially homogeneous", $M=$ $1.90(S D=1.03), t(56)=6.76, p=.00$. Consistent results were found for the reverse-coded item "Do you believe that your group is racially heterogeneous" with a significantly lower mean for the low potential faultline groups $M=1.61(S D=.91)$, with $1=$ not at all and $5=$ a lot, compared 
to the high potential faultline groups, $M=3.63(S D=1.21), t(56)=6.27, p=.00$. Similar results were found for the items referring to ethnicity. Participants in the low potential faultline groups were significantly more likely to rate their groups as ethnically homogeneous groups on the pre-experimental questionnaire, $M=4.50(S D=.57)$, with $1=$ not at all and $5=\mathrm{a}$ lot, than were participants in the high potential faultline groups when responding to the item "Do you believe that the members of your group are ethnically alike?", $M=2.39(S D=1.23), t(56)=$ $3.37, p=.00$. The responses were similar with the reverse-coded item "Do you believe that the members of your group are ethnically diverse?", in that the low potential faultline groups had a significantly lower mean, $M=2.00(S D=.81)$, than groups in the high potential faultline condition, $M=3.44(S D=1.23), t(56)=2.28, p=.03$.

In addition, regarding the leadership manipulation check and as expected, participants in the two-leader groups were significantly more likely to rate their groups as showing dual leadership on the post-experimental questionnaire, $M=2.29(S D=1.03)$, with $1=$ not at all and $5=\mathrm{a}$ lot, than were participants in the no-clear-leader groups when responding to the item "Do you believe that your group has two (and only two) clear leaders?", $M=1.38(S D=.71), t(55)=$ $3.25, p=.00$, thus indicating that the experimental conditions were satisfied.

\section{Results}

Correlations among the variables in this study are shown in Table 4. Potential ethnic faultlines and active ethnic faultlines are not correlated, suggesting the expected distinction between the two constructs. Potential ethnic faultlines are negatively and significantly intercorrelated with intersubgroup relationship conflict and positively and significantly correlated with perceived and objective group performance and member satisfaction. Active ethnic faultlines were positively and significantly intercorrelated with coalitions and intersubgroup relationship conflict. Coalitions were significantly and negatively correlated with perceived performance, satisfaction, and creativity. Intersubgroup relationship conflict was significantly and negatively intercorrelated with all group and individual outcomes and intersubgroup task conflict was significantly and negatively intercorrelated with member satisfaction and group creativity. 
In the overall multivariate analysis of variance (MANOVA), the main effects for potential ethnic faultlines, $F(8,74)=2.19, p=.04$, leadership, $F(8,74)=2.95, p=.01$, and the interaction (potential ethnic faultlines/leadership) on the hypothesized dependent variables were obtained, $F(8,74)=1.88, p=.07$. Specifically, groups with potential ethnic faultlines (demographic member alignment across race and national heritage lines) and with leadership profiles of two leaders with strong ethnic identity and strong entitlement beliefs were more likely to have activated ethnic faultlines than groups with low ethnic faultline potential, $F(1,81)=$ $4.98, p=.03$, providing support for Hypothesis 1 . In addition, groups with potential ethnic faultlines were more likely to have lower levels of intersubgroup relationship conflict, $F(1,81)$ $=15.39, p=.00$, and intersubgroup task conflict, $F(1,81)=6.42, p=.01$, than were groups with low potential ethnic faultlines, respectively. Groups with potential ethnic faultlines had higher levels of perceived performance and member satisfaction, $F(1,81)=5.05, p=.03 ; F(1,81)=$ $5.43, p=.02$, than low potential ethnic faultline groups, respectively.

In support of hypothesis 2 , groups with active faultlines were more likely to form coalitions, $M=1.95(S D=.76)$, than groups with no active faultlines, $M=1.46(S D=.39), F(1$, $82)=13.48, p=.00$, and groups with activated group faultlines were also more likely to engage in intersubgroup relationship conflict, $M=1.58(S D=.79)$, than groups with no active faultlines, $M=1.31(S D=.43), F(1,82)=3.87, p=.05$. There were no significant differences across groups for intersubgroup task conflict.

Finally, to examine hypothesis 3 (groups with subgroup coalitions will be more likely to have low levels of member satisfaction, performance, and creativity than groups without coalitions), hypothesis 4 (groups with intersubgroup relationship conflict will be more likely to have low levels of member satisfaction, performance, and creativity than groups with low levels of intersubgroup relationship conflict) and hypothesis 5 (groups with intersubgroup task conflict will be more likely to have low levels of member satisfaction, and higher levels of performance and creativity than groups with low levels of intersubgroup task conflict) we conducted ANOVAs. Members in groups with coalition formation had lower levels of member satisfaction, $M=3.98(S D=.91), F(1,84)=3.98, p=.05$, lower levels of perceived performance, $M=3.38$ $(S D=1.21), F(1,84)=3.25, p=.07$, and lower levels of creativity, $M=24.83(S D=13.15), F$ $(1,22)=8.56, p=.01$ than groups with low coalition formation $M=4.35(S D=.64), M=3.85$ $(S D=1.06)$, and $M=39.50(S D=11.41)$, respectively. Members in groups with low levels of 
intersubgroup relationship conflict had higher levels of satisfaction, $M=4.25(S D=.63)$, compared to members in groups with the higher levels of intersubgroup relationship conflict, $M$ $=3.94(S D=1.01), F(1,84)=3.30, p=.07$. Members in groups with low levels of intersubgroup task conflict had higher levels of satisfaction, $M=4.34(S D=.66)$, compared to members in groups with the higher levels of intersubgroup task conflict, $M=3.87(S D=.93), F$ $(1,84)=7.21, p=.01$.

Furthermore, although the results for conflicts did not reach significance given the small sample size at the group level, the results for group performance were in the hypothesized direction. Groups with the higher levels of intersubgroup relationship conflict performed worse and produced shorter towers, $M=56.60(S D=29.65)$, than groups with the lower levels of relationship conflict, $M=62.85(S D=30.12), F(1,22)=.26, p=.61$ (n.s.). Groups with the higher levels of intersubgroup task conflict performed better and produced taller towers, $M=$ $65.71(S D=31.74)$, than groups with the lower levels of task conflict, $M=52.65(S D=26.04), F$ $(1,22)=1.18, p=.29$ (n.s.).

\section{Supplemental Analyses}

Two sets of hierarchical regression analyses were conducted to retain the continuous nature of our scaled variables (active faultlines, coalition formation, and intersubgroup conflict), which is lost in the above ANOVA analyses where they are used as independent variables. The hierarchical analyses also allows us to examine the relative contribution of the interaction effect of potential faultlines and the leadership condition above and beyond the main effects, as well examining the relative contribution of coalition formation and intersubgroup conflict above and beyond the effects of the faultline, leadership, and interaction variables. Results are, in general, consistent with the ANOVA analyses and presented in Tables 5 and 6 . In the first set of regression analyses which examine coalitions and intersubgroup conflict as dependent variables (see Table 5), we entered a control variable, group size, in the first step of the analyses. In the second step, we entered main effects: potential ethnic faultlines, leadership profile condition, and active group faultlines. In the third step, we added the interaction of potential faultlines and the leadership profile. Potential ethnic faultlines were negatively related to intersubgroup relationship and task conflict while active faultlines were positively related to coalition formation and intersubgroup relationship and task conflict. These effects, as indicated by the significant change in R squared from step 1 to step 2, are significant above and beyond the control variable. 
The interaction of potential ethnic faultlines and the leadership condition was significant for both intersubgroup relationship and task conflict and the change in R squared from step 2 to step 3 for both of these equations indicated a significant increase above and beyond the previous step which included the main effects. In general, the variables in the model accounted for $11 \%$ of the variance in coalition formation, $47 \%$ of the variance in intersubgroup relationship conflict, and $18 \%$ of the variance in intersubgroup task conflict.

\section{INSERT TABLE 5 ABOUT HERE}

In the second hierarchical regression analyses which examine member satisfaction, perceived performance, group objective performance and group creativity as dependent variables, we include similar steps 1-3 as in the prior set of regressions and an additional step 4 which includes coalition formation, intersubgroup relationship and task conflict as independent variables in the model. Potential ethnic faultlines were positively related to perceived performance and satisfaction while active faultlines was negatively associated with member satisfaction. These effects, as indicated by the significant change in R squared from step 1 to step 2, are significant above and beyond the control variable. The interaction of potential ethnic faultlines and the leadership condition was marginally significant for member satisfaction. Finally, coalitions were negatively related to perceived performance, member satisfaction (marginally significant), and objective group-level performance (marginally significant). Task conflict was negatively associated with member satisfaction. The process variables added in step 4 (coalition formation and intersubgroup conflict) accounted for an additional 17\%, 18\%, and $25 \%$ of the variance in satisfaction, objective performance, and creativity, respectively; however, the results at the group-level of analysis rarely reach significance. In general, the variables in the model accounted for $40 \%$ of the variance in member satisfaction, $15 \%$ of the variance in perceived performance, and $31 \%$ of the variance in objective performance.

\section{INSERT TABLE 6 ABOUT HERE}

\section{Discussion}

A multimethod, multimeasurement experiment examined the relationship of group composition, group leadership profiles, and conflict, coalition formation, and group outcomes. We introduced a new conceptualization of group composition based on member alignment which builds on faultline theory (Lau \& Murnighan, 1998). Past group composition research has 
focused on the heterogeneity concept, that is, the variation around a demographic characteristic across group members. One limitation of this past work is that it has focused mainly on the examination of group member variation regarding one demographic characteristic at a time, ignoring that individuals possess multiple demographic characteristics and the social interaction process of alignment across these multiple characteristics. In contrast, the alignment construct we introduce takes into account the combination of multiple demographic characteristics and their alignment across group members to predict group processes and outcomes. The alignment construct is based on the theory of group faultlines, which to date had yet to be empirically tested. A faultline within a group based on demographic alignment of members (e.g., a 4member group with two Jamaican black members and two white Canadian members) has the potential to split the group into subgroups based on the alignment of those demographic characteristics. This conceptualization acknowledges that individuals possess multiple identities simultaneously (e.g., race, national heritage) thus reconceptualizing the traditional understanding of diversity as heterogeneity, or dispersion around one demographic characteristic, into a more thorough conceptualization incorporating identification with more than one aspect of each group member as they interact with one another.

We also distinguish between potential versus active faultlines, theorizing that the objective demographic characteristics that members may align on, while present, are not automatically noticed by group members and thus do not necessarily become activated such that group members perceive this alignment. For example, in the above 4-member group example of two Jamaicans and two Canadians, the members may not focus and form views based on other members objective demographic characteristics (i.e., black versus white). In fact, we propose that certain characteristics of the leader(s) and the leadership profile of the group are necessary to activate potential faultlines into subgroup splits. This study examined two characteristics of group leaders, the strength of a leader's ethnic identity and his or her sense of entitlement. We proposed that leaders who possess a strong sense of ethnic identity will be more likely to encourage members to align along racial or ancestral heritage lines forming an ingroup/outgroup bias leading to subgroup formation within the group. In addition, we hypothesized that leadership characteristics associated with entitlement, or the feeling of deserving regardless of effort, such as authority seeking, grandiosity, and coalition building will also increase the likelihood that groups in which members are ethnically aligned will form competitive subgroups. 
We stress in our theorizing that potential group faultlines do not necessarily turn into active group divisions, and in fact, in contrast to what much diversity research and even the initial faultline theory would propose, we hypothesized and found that potential ethnic faultines (the existence of objective demographic characteristics that are aligned across members), if not negatively activated into destructive splits by high entitlement, high ethnic-identity leaders, can enhance group processes and outcomes.

We present a multistage model in which potential faultlines activated by certain leadership profiles (high ethnic identity x high entitlement beliefs) will become active faultlines with group subdivisions, or coalitions, that can then lead to various types of conflict which ultimately affect group outcomes. We elaborate past theories of intragroup conflict by examining the dynamic process by which subgroup divisions cause competitive coalitions which can incite intersubgroup task and relationship conflict. This study therefore contributes to the literature on group processes by proposing and testing a stage model of coalition formation and conflict escalation. First, potential faultlines are based on the objective demographics of group members, yet do not necessarily cause the group to split along ethnic lines. However, potential faultlines are a precondition for the existence of active faultlines. Second, active faultlines exist when the members actually align along various demographic lines, perceive, and behave as if they are two separate, different (and potentially even opposed) groups and these are encouraged by certain profiles of leadership within the group. Third, the alignment of group members is likely to generate coalitional activity because emerging subgroups may desire to maintain separate identities to preserve their unique subgroup cultures and ensure resources. Finally, conflict is likely to arise through coalition formation. Therefore, we propose a new perspective on conflict escalation through activation of group faultlines within a group and conduct an empirical test of this model.

Another contribution of this research is its multimethod approach to the study of group processes. We feel this is especially important in the study of concepts that have been theorized about (i.e., group faultlines), but not to date empirically examined. An objective of the current study was to develop appropriate measures of such constructs and to examine their validity through triangulation of multiple measurement techniques. To enhance construct validity and advance much past group research that often relies on single-measurement methodology, we incorporated five measurement methodologies: pre- and post-experimental questionnaires, 
contextual ratings by independent raters, content-analyzed audiotapes, observational reports with behavioral indicators, and objective measures of group performance. In addition, we develop an algorithm to assess the faultline potential of a group; note that this algorithm can be used to examine multiple demographics (not just the two that we have chosen for this study of 4-person groups) to determine the member alignment within groups of any size. The algorithm allows a weighting procedure by which researchers can assess multiple racial and national heritage identities of members, as well as incorporating their gender, age, sexual orientation, religion, and other demographic characteristics into the alignment construct as the researcher desires.

Findings of the current study indicate that groups with both potential ethnic faultlines and leaders with strong ethnic identity and strong entitlement beliefs are more likely to have activated ethnic faultlines than groups with low ethnic faultline potential. Once faultlines were activated under these leadership conditions, groups were more likely to engage in coalition formation and intersubgroup relationship conflict than groups with no active faultlines. This is consistent with current work on self-percieved superiority and narcisism (Kirkpatrick, Waugh, Valencia, \& Webster, 2002; Wallace \& Baumeister, 2002) and extends it to the group level indicating that members with certain leadership characteristics can promote splits within groups and exacerbate conflict and negative group processes.

Our results provide support that activated group faultlines result in coalition formation. Consistent with the theory and our predictions, when group faultlines are activated, group members are likely to build alliances and eventually form coalitions. Consistent with findings of research on interindividual-intergroup discontinuity (Insko \& Schopler, 1987; Wildschut, Insko, $\&$ Gaertner, 2002), this provides further support that shared self-interest within a subgroup can lead to competition with another group, distrust with other group members, and relationshipfocused conflicts with members of the opposing group. Further, we also found a difference in the effects of coalitions on intersubgroup relationship conflict versus the effects of coalitions on intersubgroup task conflict, the latter type of conflict often being more constructive within groups (Amason, 1996; Jehn, 1995). In particular, we found that coalitions formed around activated ethnic faultlines were more likely to result in intersubgroup relationship conflict than in intersubgroup task conflict. This finding also provides continued empirical support for the base constructs of task and relationship conflict as conceptually different constructs, extending this to the intersubgroup conflict level. 
We also found that when subgroup coalitions formed, there were low levels of member satisfaction, perceived performance, and creativity. In addition, members in groups with intersubgroup relationship conflict had low levels of satisfaction, as did members in groups with task conflict. Results regarding group performance, while not significant due to a decreased sample size at the group level, were in the hypothesized direction such that groups with high levels of intersubgroup relationship conflict performed worse and groups with higher levels of task conflict performed better suggesting that while groups with intersubgroup relationship conflict will be more likely to have low levels of group performance, groups with intersubgroup task conflict will be more likely to have higher levels of performance. This is consistent with the previous research findings on intragroup conflict (Jehn, 1995; Jehn, Northcraft, \& Neale, 1999) in that we found that while both relationship and task conflicts were negatively associated with group members' satisfaction, there is some indication that even intersubgroup task conflict can increase a group's performance due to a focus on constructive task-focused debate rather than interpersonal attacks (Baron, 1991).

A possible direction of future research based on this model is to explore whether the faultline effects hold across different types of tasks and populations. Past research has demonstrated that the type of task a group performs is a key moderator of the relationship between diversity and performance (Jehn, Northcraft, \& Neale, 1999; Williams \& O’Reilly, 1998). For example, one past study has found that groups performing cognitive decision-making tasks benefited from diverse ideas of group members, while groups performing repetitive motor tasks were counterproductive due to losses in efficient processing (Shah \& Jehn, 1993). Since the current study examines the effects of ethnic faultlines using a motor task simulation similar to Shah and Jehn's repetitive motor task, we believe that adding another condition into the research design (e.g., cognitive task vs. motor task) would allow us to gain insight into how the nature of the task would affect group faultline processes. However, the sample size at the group level already provides challenges to the power of statistical testing in the current study and a more complex design would increase the need for a large number of groups in the experimental design. Another option, given this sample size limitation, is to focus on individual-level outcomes, but this defeats one of the main purposes of group research (and the current study) to examine the effects of member interaction on group-level processes and outcomes. 
Another area for future empirical research on faultlines to further extend work on group composition which was not examined in the current study, is to explore the differences between the effects of one-person faultline splits (e.g., a token member different from all other members who tend to be similar on multiple demographic characteristics) compared to the effects of subgroup splits on the group processes and performance outcomes in a group. Research on tokens and tokenism can provide a useful framework for this analysis. According to the Kanter's (1977) original tokenism theory and subsequent refinements (e.g., Yoder, 1991; Zimmer, 1988), dominant groups will exaggerate differences between themselves and the tokens resulting in negative consequences for the token including performance pressures resulting from their heightened visibility and exclusion from informal interactions with peers. Therefore, we believe that the effects of one-person faultline splits may produce and trigger more severe impediments in group functioning than the effects that subgroup splits cause. Also, as group size increases, three and possibly four subgroups could form thus increasing exponentially the potential for competitive coalitions and intersubgroup conflict. The faultline algorithm introduced in this study allows the calculation of all possible splits within a group (e.g., one-person splits, or splits of a large group into three or even four subgroups) and can therefore be a crucial operational tool in conducting an empirical test of these contrasting models.

In this study, we found support that potential ethnic faultlines did not evolve automatically into active group faultlines. Although a potential ethnic faultline might exist, it does not necessarily lead to the eruption of a group faultline. Interestingly, groups with potential ethnic faultlines and no faultline activation had lower levels of intersubgroup relationship conflict and higher levels of perceived performance and member satisfaction than groups with faultline activation. This is consistent with some heterogeneity research that suggest that certain types of demographic diversity may actually improve group processes (Eagly \& Wood, 1991; Jehn, Northcraft, \& Neale, 1999; Williams \& O’Reilly, 1998; Zenger \& Lawrence, 1989). We add to this literature by showing that this can be especially so if there is more than one member with the demographic characteristic (potential alignment) and the group does not have leaders focused on self-enhancement and promoting their ethnic identity within the group to cause coalition formation and competition among members. We believe this is an important finding warranting further investigation as to how a potential ethnic faultline might dissolve instead of escalating into an activated faultline with negative consequences. This would contribute to both 
practical and theoretical work on conflict management in the context of ethno-political violence, which has become a focus of social psychologists with the increase in armed ethnic conflicts (Chirot, 1997; O’Leary \& McGarry, 1995; Wildschut, Insko, \& Gaertner, 2002). 


\section{References}

Amason, A.C. (1996). Distinguishing the effects of functional and dysfunctional conflict on strategic decision making: Resolving a paradox for top management teams. Academy of Management Journal, 39(1), 123-148.

Amason, A.C., \& Schweiger, D.M. (1997). The effects of conflict on strategic decision making effectiveness and organizational performance. In Carsted K.W. De Dreu \& Evert Van de Vliert (Eds.), Using Conflict in Organizations (pp. 101-115). Thousand Oaks, CA: Sage Publications, Inc.

Amason, A.C., \& Mooney, A.C. (1999). The effects of past performance on top management team conflict in strategic decision making. International Journal of Conflict Management, 10(4), 340-359.

Ancona, D.G., \& Caldwell, D.F. (1992). Demography and design: Predictors of new product team performance. Organization Science, 3(3), 321-341.

Baron, R.A. (1991). Positive effects of conflict: A cognitive perspective. Employee Responsibilities and Rights Journal, 4(1), 25-36.

Barry, B. \& Stewart, G.L. (1997). Composition, process and performance in selfmanaged groups: The role of personality. Journal of Applied Psychology, 82(1), 62-78.

Baumeister, R.F., Smart, L., \& Boden, J.M. (1996). Relation of threatened egotism to violence and aggression: The dark side of self-esteem. Psychological Review, 103, 5-33.

Blau, P. (1977). Inequality and composition: A primitive theory of social structure. New York: Free Press.

Brewer, M.B. (1995). Managing diversity: The role of social identities. In S.E. Jackson \& M.N. Ruderman (Eds.), Diversity in work teams: Research paradigms for a changing workplace (pp. 47-68). American Psychological Association.

Brewer, M.B. (1996). When contact is not enough: Social identity and intergroup cooperation. International Journal of Intercultural Relations, 20(3-4), 291-303.

Brewer, M.B. (2000). Reducing prejudice through cross-categorization: Effects of Multiple Social Identities. In S. Oskamp (Ed.), Reducing prejudice and discrimination (pp. 165184). Mahwah, NJ: Erlbaum.

Chirot, D. (1997). Some propositions, lessons, and predictions about tyranny. Modern tyrants: The power and prevalence of evil in our age. New York: Free Press.

Connor, W. (1994). Man is a rational animal. In Ethnonationalism: The quest for understanding (pp. 195-209). Princeton, NJ: Princeton university Press.

Cook, T.D., Campbell, D.T., \& Peracchio, L. (1990). Quasi experimentation. In Marvin D. Dunnette \& Leaetta M. Hough (Eds.), Handbook of industrial and organizational psychology, 1(2), (pp. 491-576). Palo Alto, CA: Consulting Psychologists Press, Inc.

Cosier, R., \& Rose, G. (1977). Cognitive conflict and goal conflict effects on task performance. Organizational Behavior and Human Performance, 19, 378-391.

Cummings, A., Zhou, J., \& Oldham, G. (1993). Demographic differences and employee work outcomes: Effects of multiple comparison groups. Paper presented at the Annual Meeting of the Academy of Management, Atlanta, GA.

Der-Karabetian, A. (1980). Relation of two cultural identities of Armenian-Americans. Psychological Reports, 47, 123-128.

Deutsch, M. (1973). The resolution of conflict: Constructive and destructive processes. New Haven \& London: Yale University Press. 
Dovidio, J.F., Kawakami, K., \& Gaertner, S.L. (2002). Implicit and explicit prejudice and interracial interaction. Journal of Personality and Social Psychology, 82(1), 62-68.

Dowson, J. H. (1992). DSM-III--R narcissistic personality disorder evaluated by patients' and informants' self-report questionnaires: Relationships with other personality disorders and a sense of entitlement as an indicator of narcissism. Comprehensive Psychiatry, 33, 397-406.

Driedger, L. (1976). Ethnic self-identity: A comparison of ingroup evaluations. Sociometry, 39, 131-141.

Duckitt, J. (1989). Authoritarism and group identification: A new view of an old construct. Political Psychology, 10, 63-84.

Eagly, A.H., \& Wood, W. (1991). Explaining sex differences in social behavior: A metaanalytic perspective. Personality and Social Psychology Bulletin, 17(3), 306-315.

Eisenhardt, K., \& Bourgeois, L. (1988). Politics of strategic decision making in highvelocity environments: Toward a midrange theory. Academy of Management Journal, 31, 737770.

Espiritu, Y. (1992). Asian American panethnicity: Bridging institutions and identities. Philadelphia: Temple, University Press.

Fearon, J.D., \& Laitin, D.D. (2000). Violence and the social construction of ethnic identity. International Organization, 54 (4), 845-877.

Frable, D.E.S. (1997). Gender, racial, ethnic, sexual, and class identities. Annual Review of Psychology, 48, 139-162.

Gaertner, S.L, \& Dovidio, J.F. (2000). Reducing intergroup bias: The common ingroup identity model. Philadelphia: Psychology Press/Taylor \& Francis.

Gaertner, S.L., Dovidio, J.F., Banker, B.S., Houlette, M., Johnson, K.M., \& McGlynn, E.A. (2000). Reducing intergroup conflict: From superordinate goals to decategorization, recategorization, and mutual differentiation. Group Dynamics: Theory, Research, \& Practice, 4(1), 98-114.

Georgopoulos, B.S. (1986). Organizational structure, problem solving, and effectiveness. San Francisco: Jossey-Bass.

Gillespie, J.J., Brett, J., M., \& Weingart, L.R. (2000). Interdependence, social motives, and outcome satisfaction in multiparty negotiation. European Journal of Social Psychology, 30, 779-797.

Glick, W., Miller, C., \& Huber, G. (1993). The impact of upper echelon diversity on organizational performance. In G. Huber \& W. Glick (Eds.), Organizational change and redesign (pp. 176-224). New York: Oxford University Press.

Goodwin, C., \& Heritage, J. (1990). Conversation analysis. Annual Review of Anthropology, 19, 283-307.

Hardin, R. (1995). Self- interest, group identity. In A. Breton, G. Galeotti, P. Salmon, \& R. Wintrobe (Eds.), Nationalism and rationality (pp.14-42). Cambridge: University Press.

Harrison, D.A., Price, K.H., \& Bell, M.P. (1998). Beyond relational demography: time and the effects of surface- and deep-level diversity on work group cohesion. Academy of Management Journal, 41(1), 96-107.

Hirschfeld, L. (1996). Race in the making. Cognition, culture, and the child's construction of human kinds. The MIT Press.

Hoffman, L. (1978). The group problem-solving process. In L. Berkowitz (Ed.), Group Processes (pp. 101-114). New York: Academic Press. 
Hoffman, L. R., \& Maier, N. R. F. (1961). Sex differences, sex composition, and group problem solving. Journal of Abnormal \& Social Psychology, 63(2), 453-456.

Hogan, R., Raskin, R., \& Fazzini, D. (1990). The dark side of charisma. In Kenneth E. Clark \& Miriam B. Clark (Eds.), Measures of leadership (pp. 343-354). West Orange, NJ: Leadership Library of America, Inc.

Hogg, M., Turner, J. \& Davidson, B. (1990). Polarized norms and social frames of reference: A test of the self-categorization theory of group polarization. Basic and Applied Social Psychology, 11, 77-100.

Hogg, M.A., Hains, S.C., \& Mason, I. (1998). Identification and leadership in small groups: Salience, frame of reference, and leader stereotypicality effects on leader evaluations. Journal of Personality and Social Psychology, 75(5), 1248-1263.

Hogg, M.A., \& Reid, S.A. (2001). Social identity, leadership, and power. In Annette Y. Lee-Chai \& John A. Bargh (Eds.), The use and abuse of power: Multiple perspectives on the causes of corruption (pp. 159-180). Philadelphia: Psychology Press.

Hraba, J., Radloff, T., \& Gray-Ray, P. (1999). A comparison of Black and White social distance. Journal of Social Psychology, 139, 536-539.

Insko, C.A., \& Schopler, J. (1987). Categorization, competition, and collectivity. In C. Hendrick (Ed.), Reviewof personality and social psychology: Group processes (Vol. 8, pp. 213251). New York: Sage.

Insko, C.A., Schopler, J., Hoyle, R.H., Dardis, G.J., \& Graetz, K.A. (1990). Individualgroup discontinuity as a function of fear and greed. Journal of Personality and Social Psychology, 58, 68-79.

Insko, C.A., Schopler, J., Drigotas, S.M., Graetz, K.A., Kennedy, J., Cox, C., \& Bornstein, G. (1993). The role of communication in interindividual-intergroup discontinuity. Journal of Conflict Resolution, 37, 108-138.

Insko, C.A., \& Schopler, J. (1998). Differential distruct of groups and individuals. In C. Sedikides, J. Schopler, \& C.A. Insko (Eds.), Intergroup cognition and intergroup behavior (pp. 75-108). Mahwah, NJ: Erlbaum.

Insko, C.A., Schopler, J., Pemberton, M.B., Wieselquist, J., McIlraith, S.A., Currey, D.P., et al. (1998). Future consequences and the reduction of interindividual-intergroup discontinuity. Journal of personality and Social Psychology, 75, 695-711.

Insko, C.A., Schopler, J., Gaertner, L., Wildschut, T., Kozar, R., Pinter, B. et al. (2001). Interindividual-intergroup discontinuity reduction through the anticipation of future interaction. Journal of Personality and Social Psychology, 80, 95-111.

Jackson, S. (1992). Team composition in organizations. In S. Worchel, W. Wood, \& J. Simpson (Eds.), Group Process and Productivity (pp. 1-12). London: Sage.

Jehn, K.A. (1995). A multimethod examination of the benefits and detriments of intragroup conflict. Administrative Science Quarterly, 40, 256-282.

Jehn, K.A. (1997). Affective and cognitive conflict in work groups: Increasing performance through value-based intragroup conflict. In Carsten K.W. De Dreu \& Evert Van de Vliert (Eds.), Using conflict in organizations (pp. 87-100). Thousand Oaks, CA: Sage Publications, Inc.

Jehn, K.A., \& Shah, P.P. (1997). Interpersonal relationships and task performance: An examination of mediating processes in friendship and acquaintance groups. Journal of Personality and Social Psychology, 72, 775-790 
Jehn, K.A., Northcraft, G., \& Neale, M. (1999). Why differences make a difference: A field study of diversity, conflict, and performance in workgroups. Administrative Science Quarterly, 44, 741-763.

Kanter, R. M. (1977). Some effects of proportions on group life: Skewed sex ratios and responses to token women. American Journal of Sociology, 82, 965-990.

Kessler, T., \& Mummendey, A. (2001). Is there any scapegoat around? Determinants of intergroup conflicts at different categorization levels. Journal of Personality and Social Psychology, 81(6), 1090-1102.

Kirkpatrick, L.A., Waugh, C.E., Valencia, A. \& Webster, G.D. (2002). The functional domain specificity of self-esteem and the differential prediction of aggression. Journal of Personality and Social Psychology, 82(5), 756-767.

Komorita, S.S., \& Kravitz, D.A. (1983). Coalition formation: A social psychological approach. In Paulus (Ed.), Basic group processes (pp. 1979-2003). New York: Springer-Verlag.

Krate, R., Leventhal, G., \& Silverstein, B. (1974). Self-perceived transformation of Negro-to-Black identity. Psychological Reports, 35, 1071-1075.

LaBianca, G., Brass, D.J., \& Gray, B. (1998). Social networks and perceptions of intergroup conflict: The role of negative relationships and third parties. Academy of Management Journal, 41(1), 55-67.

Lau, D., \& Murnighan, J.K. (1998). Demographic diversity and faultlines: The compositional dynamics of organizational groups. Academy of Management Review, 23, 325340.

Lawler, E.J. \& Youngs, G.A. (1975). Coalition formation: An integrative model. Sociometry, 38, 1-17.

Levine, J.M., Moreland, \& R.L. (1990). Progress in small group research. Annual Review of Psychology, 585-634.

Mannix, E.A. (1993). Organizations as resource dilemmas: The effects of power balance on coalition formation in small groups. Organizational Behavior and Human Decision Processes, 55, 1-22.

Mazur, A. (1973). Cross-species comparison of status in established small groups. American Sociological Review, 38, 513-529.

McBeth, S. (1989). Layered identity systems in western Oklahoma Indian communities. Paper presented at the annual meeting of the American anthropological Association.

McGuire, W. J., McGuire, C. V., Child, P., \& Fujioka, T. (1978). Salience of ethnicity in the spontaneous self-concept as a function of one's ethnic distinctiveness in the social environment. Journal of Personality and Social Psychology, 36, 511-520.

Moore, D. (1991). Entitlement and justice evaluations: Who should get more, and why. Social Psychology Quarterly, 54(3), 208-223.

Morten, G., \& Atkinson, D.R. (1983). Minority identity development and preference for counselor race. Journal of Negro Education, 52, 156-161.

Mullick, R., \& Hraba, J. (2001). Ethnic attitudes in Pakistan. International Journal of Intercultural Relations, 25, 165-179.

Murnighan, J.K., \& Brass, D.J. (1991). Intraorganizational coalitions. In M.H.Bazerman, R.J.Lewicki, \& B.H. Sheppard (Eds.), Research on negotiation in organizations: The handbook of negotiation research. Greenwich, CT: JAI Press.

Nagel, J. (1994). Constructing ethnicity: Creating and recreating ethnic identity and culture. Social Problems, 41, 152-176. 
Nkomo, S.M. The emperor has no clothes: Rewriting "race in organizations." Academy of Management Review, 17(3), 487-513.

Northcraft, G.B., Polzer, J.T., Neale, M.A., \& Kramer, R.M. (1995). Diversity, social identity, and performance: Emergent social dynamics in cross-functional teams. In Susan E. Jackson \& Marian N. Ruderman (Eds.), Diversity in work teams: Research paradigms for a changing workplace (pp.69-96). American Psychological Association.

O'Leary, B., \& McGarry, J. (1995). Regulating nations and ethnic communities. In A. Breton et al., (Eds.), Nationalism and rationality. (pp. 245-289). New York: Cambridge University Press.

O'Reilly, C. \& Flatt, S. (1989). Executive team demography: Organizational innovation and firm performance. Working paper, School of Business, University of California at Berkeley.

O'Reilly, C.A. III, Williams, K.Y., \& Barsade, S. (1998). Group demography and innovation: Does diversity help? In Deborah H. Gruenfeld (Ed.), Composition. Research on managing groups and teams, 1 (pp. 183-207). Stamford, CT: JAI Press, Inc.

Padilla, F. (1985). Latino ethnic consciousness: The case of Mexican American and Puerto Ricans in Chicago. Notre Dame: University of Notre Dame Press.

Pearce, J.A., \& DeNisi, A.S. (1983). Attribution theory and strategic decision making: An application to coalition formation. Academy of Management Journal, 26(1), 119-128.

Pelled, L.H. (1996). Relational demography and perceptions of group conflict and performance: A field investigation. International Journal of Conflict Management, 7(3), 230246.

Phinney, J.S. (1992). The multigroup ethnic identity measure: A new scale for use with diverse groups. Journal of Adolescent Research, 7(2), 156-176.

Phinney, J.S. (1996). Understanding ethnic diversity: The role of ethnic identity. American Behavioral Scientist, 40(2), 143-152.

Polzer, J.T., Mannix, E.A., \& Neale, M.A. (1998). Interest alignment and coalitions in multiparty negotiation. Academy of Management Journal, 41, 42-54.

Pratto F., Sidanius, J., \& Stallworth, L.M. (1993). Sexual selection and the sexual ethnic basis of social hierarchy. In L. Ellis (Ed.), Social stratification and socioeconomic inequality: A comparative biosociological analysis (pp. 111-137). New York: Praeger.

Rabbie, J.M., \& Bekkers, F. (1978). Threatened leadership and intergroup competition. European Journal of Social Psychology, 8, 9-20.

Raskin, R., \& Terry, H. (1988). A principal-components analysis of the narcissistic personality inventory and further evidence of its construct validity. Journal of Personality and Social Psychology, 54(5), 890-902.

Raskin, R., Novacek, J., \& Hogan, R. (1991). Narcissistic self-esteem management. Journal of Personality and Social Psychology, 60(6), 911-918.

Rosenthal, D.A., \& Hrynevich, C. (1985). Ethnicity and ethnic identity: A comparative study of Greek-, Italian-, and Anglo-Australian adolescents. International Journal of Psychology, 20, 723-742.

Rousseau, D.M. (1985). Issues of level in organizational research: Multi-level and crosslevel perspectives. Research in Organizational Behavior, 7, 1-37

Schopler, J., Insko, C.A., Graetz, K.A., Drigotas, S.M., Smith, V.A., \& Dahl, K.A. (1993). Individual-group discontinuity: Further evidence for mediation by fear and greed. Personality and Social Psychology Bulletin, 19, 419-431. 
Schweiger, D. M., Sandberg, W., \& Rechner, P. (1989). Experiential effects of dialectical injury, devil's advocacy, and consensus approaches to strategic decision making. Academy of Management Journal, 32, 745-772.

Shah, P.P., \& Jehn, K.A. (1993). Do friends perform better than acquaintances? The interaction of friendship, conflict, and task. Group Decision and Negotiation, 2(2), 149-165.

Sherif, M., Harvey, O.J., White, B.J., Hood, W.R. \& Sherif, C.W. (1961). Intergroup conflict and cooperation: The Robbers Cave experiment. Norman: University of Oklahoma Book Exchange.

Silverman, J. G., \& Williamson, G. M. (1997). Social ecology and entitlements involved in battering by heterosexual college males: Contributions of family and peers. Violence \& Victims, 12, 147-164.

Simons, T.L., \& Peterson, R.S. (2000). Task conflict and relationship conflict in top management teams: The pivotal role of intragroup trust. Journal of Applied Psychology, 85(1), 102-111.

Singh, V. (1977). Some theoretical and methodological problems in the study of ethnic identity: A cross-cultural perspective. New York Academy of Sciences: Annals, 285, 32-42.

Singleton, R.A., Jr., Straits, B.C., \& Miller, M. (1993). Approaches to social research (2nd ed.). New York: Oxford University Press.

Steiner, I.D. (1972). Group process and productivity. San Diego: Academic Press.

Stevenson, W. B., Pearce, J. L., \& Porter, L. W. (1985). The concept of "coalition" in organizational theory and research. Academy of Management Review, 10, 256-268.

Tajfel, H. (1982). Social psychology of intergroup relations. Annual Review of Psychology, 33, 1-39.

Tajfel, H., \& Turner, J.C. (1986). The social identity theory of intergroup behavior. In Worchel \& Austin (Eds.), Psychology of intergroup relations, $2^{\text {nd }}$ ed. (pp. 7-24). Chicago: Nelson-Hall.

Ten Have, P. (1986). Methodological issues in conversational analysis. Bulletin de Méthodologie Sociologique, 27, 23-51.

Thatcher, S.M., Jehn, K.A., \& Zanutto, E. (in press). Cracks in diversity research: The effects of faultlines on conflict and performance.

Thompson, L.L., Mannix, E.A., \& Bazerman, M.H. (1988). Group negotiation: Effects of decision rule, agenda, and aspiration. Journal of personality and social psychology, 54(1), 86-95.

Thornburg, T. (1991). Group size and member diversity influence on creative performance. Journal of Creative Behavior, 25, 324-333.

Tyerman, A., \& Spencer, C. (1983). A critical test of the Sherifs' robber's cave experiments: Intergroup competition and cooperation between groups of well-acquainted individuals. Small Group Behavior, 14, 515-531.

U.S. Census Bureau, 2002. http://www.census.gov.

Verdery, K. (1993). Whither "Nation" and "Nationalism"? Daedalas, 122(3), 37-46.

Wallace, H.M. \& Baumeister, R.F. (2002). The performance of narcissists rises and falls with perceived opportunity for glory. Journal of Personality and Social Psychology, 82(5), 819834.

Waters, M. (1996). The intersection of gender, race, and ethnicity in identity development of Caribbean American teens. In B. Leadbeater \& N. Way (Eds), Urban girls: Resisting stereotypes, creating identities (pp. 65-81). New York University Press. 
Weber, M. (1997). What is an ethnic group? In Montserrat Guibernau \& John Rex (Eds.), The ethnicity reader: Nationalism, multiculturalism and migration (pp. 17-26). Polity Press.

Weingart, L.R. (1992). Impact of group goals, task component complexity, effort, and planning on group performance. Journal of Applied Psychology, 77(5), 682-694.

Weldon, E., Jehn, K.A., \& Pradhan, P. (1991). Processes that mediate the relationship between a group goal and improved group performance. Journal of Personality and Social Psychology, 61, 555-569.

Wildschut, T., Insko, C.A., \& Gaertner, L. (2002). Intragroup social influence and intergroup competition. Journal of Personality and Social Psychology, 82(6), 975-992.

Williams K., \& O’Reilly, C. (1998). Demography and Diversity in Organizations: A Review of 40 Years of Research. Research in Organizational Behavior, 20, 77-140.

Yancey, A. K., Aneshensel, C. S., \& Driscoll, A. K. (2001). The assessment of ethnic identity in a diverse urban youth population. Journal of Black Psychology, 27, 190-208.

Yoder, J. D. (1991). Rethinking tokenism: Looking beyond numbers. Gender and Society, 5, 178-192.

Zenger, T.R., \& Lawrence, B.S. (1989). Organizational demography: The differential effects of age and tenure distributions on technical communication. Academy of Management Journal, 32(2), 353-376.

Zimmer, L. (1988). Tokenism and women in the workplace: The limits of gender-neutral theory. Social Problems, 35, 64-77. 
Table 1: Factor Loadings for Ethnic Identity, Entitlement, Faultlines, and Coalitions

\begin{tabular}{|c|c|c|c|c|}
\hline Measure & $\begin{array}{l}\text { Factor } 1 \\
\text { (Ethnic } \\
\text { Identity) }\end{array}$ & $\begin{array}{c}\text { Factor } 2 \\
\text { (Entitlement } \\
\text { ) }\end{array}$ & $\begin{array}{c}\text { Factor } 3 \\
\text { (Faultline) }\end{array}$ & $\begin{array}{c}\text { Factor } 4 \\
\text { (Coalition) }\end{array}$ \\
\hline $\begin{array}{l}\text { "I am a person who feels strong bonds toward my ethnic } \\
\text { group." (EQ) }\end{array}$ & $\underline{-.93}$ & -.08 & -.03 & .06 \\
\hline "I feel an overwhelming attachment to my ethnic group." (EQ) &.- .84 & .03 & -.09 & .11 \\
\hline "I am proud to identify with my own ethnic group." (EQ) & -.87 & .07 & .08 & -.14 \\
\hline $\begin{array}{l}\text { "I feel excitement and joy in my own ethnic group's } \\
\text { surroundings." (EQ) }\end{array}$ & $\underline{-.91}$ & .05 & -.05 & -.05 \\
\hline I consider my own ethnic culture rich and precious. (EQ) & $\underline{-.87}$ & -.09 & -.05 & -.07 \\
\hline Content analysis of verbatim for entitlement (CA) & .03 & $\underline{.48}$ & .11 & .16 \\
\hline Contextual ratings of entitlement (CR) & .14 & $\underline{.55}$ & -.06 & .03 \\
\hline $\begin{array}{l}\text { "I feel entitled to certain things even if I put in little effort." } \\
\text { (EQ) }\end{array}$ & -.26 & .84 & -.03 & -.01 \\
\hline $\begin{array}{l}\text { "I feel I am worthy of having everything without significant } \\
\text { exertion of mental or physical energy." (EQ) }\end{array}$ & -.05 & $\underline{.92}$ & .05 & .01 \\
\hline $\begin{array}{l}\text { "I feel I am entitled to certain privileges even if I don't } \\
\text { contribute." (EQ) }\end{array}$ & -.09 & .90 & .03 & -.11 \\
\hline $\begin{array}{l}\text { "I feel I deserve a piece of the world because I am an } \\
\text { extraordinary person." (EQ) }\end{array}$ & .13 & .77 & -.09 & -.10 \\
\hline Open-ended question for faultline (OEQ) & .03 & -.06 & $\underline{.84}$ & -.07 \\
\hline Content analysis of verbatim for faultline (CA) & -.01 & .01 & .77 & -.28 \\
\hline Contextual ratings of faultline (CR) & -.06 & .10 &.$\underline{.61}$ & -.02 \\
\hline "My team split into subgroups during this exercise." (EQ) & .15 & -.01 & .71 & .18 \\
\hline $\begin{array}{l}\text { "My team divided into subsets of people during this exercise." } \\
\text { (EQ) }\end{array}$ & .12 & .05 & .74 & .12 \\
\hline "My team broke into two groups during this exercise." (EQ) & .08 & -.10 & .70 & .18 \\
\hline Contextual ratings of coalition (CR) & -.20 & .02 & .32 & $\underline{.35}$ \\
\hline $\begin{array}{l}\text { "My team members were trying to form coalitions during this } \\
\text { exercise." (EQ) }\end{array}$ & -.04 & -.09 & -.07 & $\underline{.88}$ \\
\hline $\begin{array}{l}\text { "People built alliances in my } 240 \text { team during this exercise." } \\
\text { (EQ) }\end{array}$ & .15 & .07 & -.01 & .86 \\
\hline $\begin{array}{l}\text { "My team members were obsessed by the idea of splitting into } \\
\text { coalitions during this exercise." (EQ) }\end{array}$ & .06 & .05 & .04 & .83 \\
\hline Eigenvalues & 5.02 & 3.64 & 3.13 & 2.02 \\
\hline
\end{tabular}

Note. Boldface and underline is used to indicate significant loading. $\mathrm{OEQ}=$ open-ended question; $\mathrm{EQ}=$ experimental questionnaire; $\mathrm{CA}=$ content analysis; $\mathrm{CR}=$ contextual ratings. 
Table 2: Factor Loadings for Task Conflict and Relationship Conflict

\begin{tabular}{|c|c|c|}
\hline Measure & $\begin{array}{c}\text { Factor } 1 \\
\text { (Task Conflict) }\end{array}$ & $\begin{array}{c}\text { Factor } 2 \\
\text { (Relationship } \\
\text { Conflict) }\end{array}$ \\
\hline Content analysis of verbatim relationship conflict (CA) & .23 & .61 \\
\hline Contextual ratings of relationship conflict (CR) & .40 & .62 \\
\hline $\begin{array}{l}\text { "How much do you think that members across different subgroups } \\
\text { within your team didn't interpersonally get along?" (EQ) }\end{array}$ & .45 & .63 \\
\hline $\begin{array}{l}\text { "Members across different subgroups within your team often disagreed } \\
\text { about non-work (social or personality) things" (EQ) }\end{array}$ & -.16 & $\underline{.83}$ \\
\hline Content analysis of verbatim task conflict (CA) & .44 & .21 \\
\hline Contextual ratings of task conflict (CR) & $\underline{.56}$ & .21 \\
\hline $\begin{array}{l}\text { "How much conflict of ideas was there across different subgroups in } \\
\text { your team during this exercise?" (EQ) }\end{array}$ & .82 & .10 \\
\hline "Members across different subgroups fought about task matters." (EQ) & $\underline{.82}$ & .28 \\
\hline $\begin{array}{l}\text { "Members across different subgroups often disagreed about task } \\
\text { things." (EQ) }\end{array}$ & $\underline{.82}$ & .18 \\
\hline $\begin{array}{l}\text { "How different were members' viewpoints across different subgroups } \\
\text { on decisions?" (EQ) }\end{array}$ & .78 & .01 \\
\hline Eigenvalues & 4.15 & 1.74 \\
\hline
\end{tabular}

Note. Boldface and underline is used to indicate significant loading. OEQ $=$ open-ended questionnaire; EQ $=$ experimental questionnaire; $\mathrm{CA}=$ content analysis; $\mathrm{CR}=$ contextual ratings 
Table 3: Factor Loadings for Team Outcomes

\begin{tabular}{|c|c|c|c|}
\hline Measure & $\begin{array}{c}\text { Factor } 1 \\
\text { (Satisfaction) }\end{array}$ & $\begin{array}{c}\text { Factor } 3 \\
\text { (Perceived } \\
\text { Performance) }\end{array}$ & $\begin{array}{c}\text { Factor } 4 \\
\text { (Creativity) }\end{array}$ \\
\hline Contextual ratings of satisfaction (CR) & $\underline{.43}$ & .38 & .31 \\
\hline $\begin{array}{l}\text { "I was happy working in this group during this exercise." } \\
\text { (EQ) }\end{array}$ & $\underline{.89}$ & -.04 & -.02 \\
\hline $\begin{array}{l}\text { "I was very satisfied working in this team during this } \\
\text { exercise." (EQ) }\end{array}$ &.$\underline{69}$ & -.25 & .06 \\
\hline "I would like to work with this team again." (EQ) & .94 & .09 & -.17 \\
\hline $\begin{array}{l}\text { "I will talk up this team to my friends as a great group to work } \\
\text { with." (EQ) }\end{array}$ & $\underline{.83}$ & .03 & -.10 \\
\hline $\begin{array}{l}\text { "There was a good feeling of group spirit in our } 240 \text { team } \\
\text { during this exercise." (EQ) }\end{array}$ & .71 & -.14 & .16 \\
\hline $\begin{array}{l}\text { "How much did you enjoy working on this task with your } \\
\text { team members." (EQ) }\end{array}$ & .76 & .03 & .18 \\
\hline Contextual ratings of performance (CR) & .15 & $\underline{-.68}$ & .26 \\
\hline "My team performed very effectively on this exercise." (EQ) & .05 & $\underline{-.93}$ & .01 \\
\hline "I performed very effectively on this exercise." (EQ) & -.19 &.- .97 & -.11 \\
\hline $\begin{array}{l}\text { "I think my work group, as a whole, performed very } \\
\text { effectively during this exercise." (EQ) }\end{array}$ & .16 & $\underline{-.85}$ & .02 \\
\hline $\begin{array}{l}\text { "I think I performed very effectively during this exercise." } \\
\text { (EQ) }\end{array}$ & -.01 & $\underline{-.92}$ & -.14 \\
\hline $\begin{array}{l}\text { "My team was very effective at getting things done quickly } \\
\text { during this exercise." (EQ) }\end{array}$ & .11 & $\underline{-.83}$ & .03 \\
\hline Objective creativity performance (OBJ) & .07 & .17 & $\underline{.85}$ \\
\hline Contextual ratings creativity (CR) & -.11 & -.07 & $\underline{.85}$ \\
\hline Eigenvalues & 7.36 & 2.45 & 1.46 \\
\hline
\end{tabular}

Note. Boldface and underline is used to indicate significant loading. OEQ $=$ open-ended question; EQ = experimental questionnaire; $\mathrm{CA}=$ content analysis; $\mathrm{CR}=$ contextual ratings; $\mathrm{OBJ}=$ objective creativity 
Table 4: Means, Standard Deviations, and Correlations Between Variables

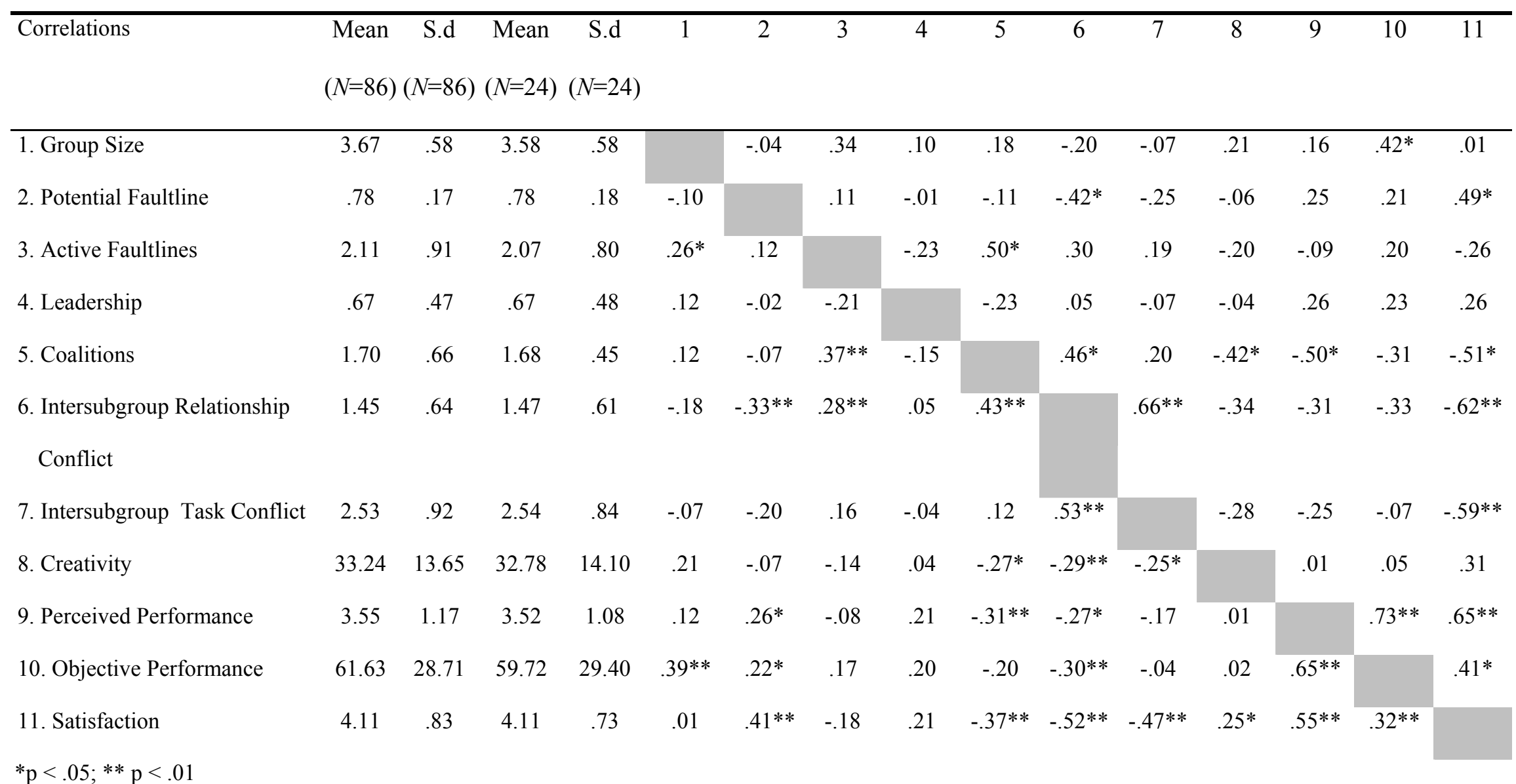

Individual level correlations are reported in the lower triangle.

Group level correlations are reported in the upper triangle. 
Table 5. Hierarchical Multiple Regressions Predicting Coalitions and Intersubgroup Conflicts

\begin{tabular}{|c|c|c|c|}
\hline Variable & $\begin{array}{l}\text { Coalitions } \\
(\mathrm{N}=86)\end{array}$ & $\begin{array}{l}\text { Intersubgroup } \\
\text { Relationship } \\
\text { Conflict } \\
(\mathrm{N}=86)\end{array}$ & $\begin{array}{l}\text { Intersubgroup } \\
\text { Task Conflict } \\
(\mathrm{N}=86)\end{array}$ \\
\hline \multicolumn{4}{|l|}{ Step 1: Controls } \\
\hline Group Size & .12 & $-.18^{\dagger}$ & -.07 \\
\hline $\mathrm{R}^{2}$ & .01 & .03 & .01 \\
\hline Adjusted $\mathrm{R}^{2}$ & .00 & .02 & -.01 \\
\hline $\mathrm{F}$ & 1.15 & $2.83^{\dagger}$ & .42 \\
\hline \multicolumn{4}{|l|}{ Step 2: Main Effects } \\
\hline Potential Ethnic Faultlines (PeFau) & -.12 & $-.43 * * *$ & $-.24 *$ \\
\hline Active Group Faultlines & $.37^{* *}$ & $.47 * * *$ & $.24 *$ \\
\hline Leadership (L) & -.07 & $.19^{*}$ & .03 \\
\hline Change in $\mathrm{R}^{2}$ & .15 & .32 & .09 \\
\hline F change & $4.65^{* *}$ & $13.03 * * *$ & $2.72^{\dagger}$ \\
\hline $\mathrm{R}^{2}$ & .16 & .35 & .10 \\
\hline Adjusted $\mathrm{R}^{2}$ & .12 & .32 & .05 \\
\hline $\mathrm{F}$ & $3.81 * *$ & $10.78 * * *$ & $2.15^{\dagger}$ \\
\hline \multicolumn{4}{|l|}{ Step 3: Interactions } \\
\hline PeFau X L & .25 & $2.62 * * *$ & $2.46^{* * *}$ \\
\hline Change in $\mathrm{R}^{2}$ & .00 & .15 & .14 \\
\hline F change & .13 & $24.42 * * *$ & $14.03 * * *$ \\
\hline $\mathrm{R}^{2}$ & .16 & .50 & .23 \\
\hline Adjusted $\mathrm{R}^{2}$ & .11 & .47 & .18 \\
\hline $\mathrm{F}$ & $3.04 *$ & $16.00 * * *$ & $4.81 * *$ \\
\hline
\end{tabular}


Table 6. Hierarchical Multiple Regressions Predicting Team Outcomes

\begin{tabular}{|c|c|c|c|c|}
\hline Variable & $\begin{array}{l}\text { Satisfaction } \\
(N=86)\end{array}$ & $\begin{array}{l}\text { Perceived } \\
\text { Performance } \\
(N=86)\end{array}$ & $\begin{array}{l}\text { Objective } \\
\text { Performance } \\
(N=24)\end{array}$ & $\begin{array}{l}\text { Creativity } \\
(N=24)\end{array}$ \\
\hline \multicolumn{5}{|l|}{ Step 1: Controls } \\
\hline Group Size & .01 & .12 & $.42 *$ & .21 \\
\hline $\mathrm{R}^{2}$ & .00 & .02 & .17 & .04 \\
\hline Adjusted $\mathrm{R}^{2}$ & -.01 & .00 & .14 & .00 \\
\hline $\mathrm{F}$ & .01 & 1.28 & $4.58^{*}$ & 1.02 \\
\hline \multicolumn{5}{|l|}{ Step 2: Main Effects } \\
\hline Potential Ethnic Faultlines (PeFau) & $.45^{* * *}$ & $.30 * *$ & .21 & -.01 \\
\hline Active Group Faultlines & $-.23 *$ & -.12 & .10 & -.33 \\
\hline Leadership (L) & .15 & .17 & .21 & -.07 \\
\hline Change in $\mathrm{R}^{2}$ & .26 & .13 & .09 & .09 \\
\hline F change & $9.49 * * *$ & $4.04 *$ & .79 & .65 \\
\hline $\mathrm{R}^{2}$ & .26 & .14 & .27 & .13 \\
\hline Adjusted $\mathrm{R}^{2}$ & .22 & .10 & .11 & -.05 \\
\hline $\mathrm{F}$ & $7.12 * * *$ & $3.39 *$ & 1.71 & .73 \\
\hline \multicolumn{5}{|l|}{ Step 3: Interactions } \\
\hline PeFau X L & $-1.09^{\dagger}$ & -1.07 & -2.16 & .48 \\
\hline Change in $\mathrm{R}^{2}$ & .03 & .03 & .10 & .01 \\
\hline F change & $2.98^{\dagger}$ & 2.45 & 2.95 & .11 \\
\hline $\mathrm{R}^{2}$ & .29 & .17 & .37 & .14 \\
\hline Adjusted $\mathrm{R}^{2}$ & .24 & .12 & .19 & -.10 \\
\hline $\mathrm{F}$ & $6.43 * * *$ & $3.25^{*}$ & 2.10 & .58 \\
\hline \multicolumn{5}{|l|}{ Step 4: Process Variables } \\
\hline Coalitions & $-.19^{\dagger}$ & $-.29 *$ & $-.42^{\dagger}$ & -.43 \\
\hline Intersubgroup Relationship conflict & -.22 & .07 & -.11 & -.16 \\
\hline Intersubgroup Task conflict & $-.29 * *$ & -.04 & .28 & -.30 \\
\hline Change in $\mathrm{R}^{2}$ & .17 & .06 & .18 & .25 \\
\hline F change & $8.25^{* * *}$ & 2.12 & 2.02 & 2.05 \\
\hline $\mathrm{R}^{2}$ & .46 & .23 & .55 & .39 \\
\hline Adjusted $\mathrm{R}^{2}$ & .40 & .15 & .31 & .06 \\
\hline $\mathrm{F}$ & $8.20 * * *$ & $2.91 * *$ & $2.29^{\dagger}$ & 1.20 \\
\hline
\end{tabular}


Appendix

\section{Coding procedure}

1. Check for accuracy of transcription by randomly selecting segments from the audiotapes and comparing them with the transcripts.

2. Divide each transcript into "thought units". A thought unit is "a sequence of a few words conveying a single thought."

3. Classify all thought units into content categories: active group faultlines, coalitions, intersubgroup conflict (task and relationship), member satisfaction, creativity, and performance.

\section{Description of content categories directly relevant to the model}

Faultines. Statements that indicate a group split through group members' commitment to a particular plan during the planning phase. The faultline score is a group-level score and it should be either 0 (no split) or 1 (split).

Examples:

A: “The proposed plan is we try [Name of the person]'s, and if it doesn't work we resort to OURS. [Name of the person]'s plan doesn't seem very promising, but we'll stick with it for a while".

B: "We have to draw two things right now. So let's draw what YOU did first, because that was pretty. And we'll draw OUR final idea, okay?"

C: "How about we divide and conquer. When this comes, YOU guys try to build that base and... then we see what works".

Coalitions. Statements or questions that indicate coalition formation through (1) whether group members were excluded explicitly as well as implicitly from the group interaction, or (2) whether there is explicit indication of division in the group across two subgroups. The coalition score is a group-level score assigned based on the cumulative number of appearance of coalition indications in the groups' transcript.

\section{Examples:}

A: "We've got to roll them tight so they don't [inaudible]".

B: "You can take two or whatever [inaudible] roll them tighter and stick them in here.

That will take care of the next level, then stick another one in [inaudible]"

C: "I'm not sure what you guys are saying. Do you want me to just keep going with this like this?" [a group member was excluded from interaction]

A: "Don't you think that's going to like wave and ..."

B: "No!" [conflict between A and B] 
C: "It might wave but then we can do something with the marshmallows and pipe

cleaners to hold them in place" [C supports A, a coalition forms between A and $\mathrm{C}$ against $\mathrm{B}]$.

Intersubgroup relationship conflict. Indications of relationship conflict through negative tones of voices, expressions of annoyance and disappointment, and personal nitpicking (even if it seems jokingly at times) across subgroups. The relationship conflict score is an individual-level score assigned based on the following rules: (1) if a comment is directed towards the other subgroup, a score is assigned only to the source of the comment, (2) if two or more people across the subgroups engage in dialogue, a score is assigned to each one who contributes verbally to the conflict.

Examples:

A: "We're not going to be able to have that many columns".

B: "I'm just making the base and put select columns together, that's all. I understand your concern".

A: "You're making a base right now?"

B: "I have no idea what I'm making. What do you want me to make? Columns?"

A: "Okay, [Name of the person], I think you're like the best drawer based on the [inaudible]. That's not to say you're a bad drawer, I'm clearly the worst".

B: "We don't need to rank each other's qualities. I'll try. What am I drawing?"

A: "You're ruining the bond, man".

B: "It was so rude of you to do that. I don't understand why you did that".

Intersubgroup task conflict. Statements that indicate a disagreement between subgroup members over different ideas or task opinions during the planning stage of the exercise. The task conflict score is an individual-level score assigned based on the following rule: a score is assigned to the people who engage in dialogue and argue over different ideas.

Examples:

A: "I personally think that if you do it this way and just build on top of it you can get a really sturdy foundation [idea \#1]'.

$\mathrm{B}$ : "But the problem is we're not going for sturdiness... I say we just start stacking tubes and using a lot of staples and see what we get [idea \#2]".

A: "...three of them, stick a marshmallow on top, push together [idea \#1]".

B: "That's not going to stand. ... Think about it. When you start building higher and higher the weight of it... I guess if you just hold the markers down until you build it and it's supported equally every way, then it will stand [idea \#2]...."

Entitlement. Statements that indicate (1) people take credit for work (even if unwarranted) and make this explicit to everybody and (2) people try to bring attention to themselves as focal 
members. The entitlement score is an individual-level score assigned based on the following rule: a score is assigned only to the source of the comment.

Examples:
A: "That's where I got my idea from! You take a credit for mine!"
B: "I'm a big chewer!!!"
C: "My drawings are spectacular. I'm an artist! I'm going to become the greatest marshmallow builder ever! I have the best drawing skills, I know".

Performance. Statements were coded into four different categories: (1) negative statements about tower and its height, (2) negative statements about people's abilities to perform, (3) positive statements about tower and its height, and (4) positive statements about people's abilities to perform. The performance score is a group-level score assigned based on the cumulative number of appearance of performance indications in the groups' transcript with negative statements reverse coded.

\section{Examples:}

A: "What do you want from me? It's not going to stand! You want me to hold it?" "This is going to be bad. These things barely stand up on their own." [Negative performance]

B: "We like weird and diversity. We like that [inaudible]. I kind of think we [failed] because we're the least diverse group. There's no diversity. No diversity. We all think the same. Bad! Bad! I'm going to eat a marshmallow. These are awesome and I want it so bad." [Negative performance]

$\mathrm{C}$ : "I think our tower right now is higher than everybody else's. Our tower is a work of art!" [positive performance]

D: "We are winning!!!" [positive performance]. 